This is the final peer-reviewed accepted manuscript of

Bruno, Luigi; Bohacs, Kevin M.; Campo, Bruno; Drexler, Tina M.; Rossi, Veronica; Sammartino, Irene;

Scarponi, Daniele; Hong, Wan; Amorosi, Alessandro: Early Holocene transgressive palaeogeography in the

Po coastal plain (northern Italy). SEDIMENTOLOGY, 64. ISSN 0037-0746

DOI: $10.1111 /$ sed.12374

The final published version is available online at: http://dx.doi.org/10.1111/sed.12374

Rights / License:

The terms and conditions for the reuse of this version of the manuscript are specified in the publishing policy. For all terms of use and more information see the publisher's website.

This item was downloaded from IRIS Università di Bologna (https://cris.unibo.it/)

When citing, please refer to the published version. 


\title{
Early Holocene transgressive palaeogeography in the Po coastal plain (northern Italy)
}

\author{
LUIGI BRUNO* , KEVIN M. BOHACS †, BRUNO CAMPO*, TINA M. \\ DREXLER†, VERONICA ROSSI*, IRENE SAMMARTINO\$, DANIELE \\ SCARPONI*, WAN HONG $\S$ and ALESSANDRO AMOROSI* \\ ${ }^{*}$ Department of Biological, Geological and Environmental Sciences, University of \\ Bologna, Via Zamboni 67, 40126 Bologna, Italy (E-mail: luigi.bruno4@unibo.it) \\ $\dagger$ ExxonMobil Upstream Research Company, 22777 Springwoods Village Parkway, \\ Spring, TX 77389, USA \\ $\$$ Geologic Consultant, 34000, Bologna, Italy \\ $\S$ KIGAM Korea Institute of Geoscience and Mineral Resources, 92 Gwahangro, Yuseong- \\ gu, Daejeon Metropolitan City, Korea \\ Associate Editor - JP Walsh
}

\begin{abstract}
To understand the complex stratigraphic response of a coastal depositional system to rapid eustatic rise and sediment inputs, the evolution of the Adriatic coastline and Po River system, during the post-glacial (Holocene) transgression, was investigated. The landward migration and evolution of a wave-dominated estuary was mapped, based on an extensive data set comprising 14 boreholes, 28 core descriptions and 308 piezocone tests, chronologically constrained between 11.5 and $7.0 \mathrm{kyr}$ BP by 137 radiocarbon dates. Palaeogeographic maps reveal temporal differences in retrogradational geometries and mechanisms that likely underpin shoreline retreat. The Po estuary initially developed within a shallowly incised valley and then spread onto the interfluves. Between 11.5 and 9.2 kyr вP the Po fluvial system became avulsive/distributive and wetlands developed in topographically depressed areas. The shoreline retreated at a mean rate of $c a 10 \mathrm{~m} \mathrm{year}^{-1}$, between $9.2 \mathrm{kyr}$ and $7 \cdot 7 \mathrm{kyr}$ BP, following a stepped trajectory at the centennial scale. After $7 \cdot 7 \mathrm{kyr}$ вP, bayhead deltas started to prograde and partially filled the estuary. The overall stratigraphic architecture is interpreted to reflect the sedimentary response of the coastal depositional system to the main pulses of early Holocene eustatic rise. The influence of antecedent topography, partly due to local subsidence, was dominant at the time of initial transgression. Basin morphology influenced sediment dispersal and partitioning. Sediment supplied by the Po River was trapped within the estuary, whereas coastal sand bodies at the estuary mouth were fed by alongshore currents and by reworking of older barriers. High-resolution age control that ties facies evolution to independently constrained eustasy provides direct data to test models of short-term coastal retreat under conditions of relative sea-level rise, and makes this case study a useful analogue for the interpretation of ancient marginal-marine, retrogradational systems where only stratal geometries are available.
\end{abstract}

Keywords Early Holocene, eustatic rise, local factors, Po coastal plain, transgressive parasequences, wave-dominated estuary. 


\section{INTRODUCTION}

Coastal areas host a large portion of the global population and are thereby highly sensitive to the effects of sea-level rise (McGranahan et al., 2007). For this reason, their response to sea-level change has received growing attention from the Earth Science community in the last decades. Many Quaternary sea-level curves have focused on the post-Last Glacial Maximum (LGM) eustatic rise (Fairbanks, 1989; Bard et al., 1996; Lambeck \& Purcell, 2005; Gregoire et al., 2012). Sea-level rose at a mean rate of 10 to $15 \mathrm{~mm}$ year $^{-1}$ between $18 \mathrm{kyr}$ and $6 \mathrm{kyr}$ вP, with short-lived pulses of rapid change (ca $20 \mathrm{~m}$ in less than 500 years; Bard et al., 1996; Clark et al., 2002) linked to significant freshwater discharge into the oceans (Liu et al., 2004).

The environmental modifications induced by post-LGM sea-level rise have been explored in numerous sites along modern coastlines (Amos \& Knoll, 1987; Vis et al., 2008; Andrés Giagante et al., 2011; Traini et al., 2013; Cawthra et al., 2014; Kowalewski et al., 2015). These studies reveal deep valleys, excavated during the Late Pleistocene sea-level fall, which were partially drowned after $18 \mathrm{kyr}$ вP to become estuaries (Allen \& Posamentier, 1993; Foyle \& Oertel, 1997; Li et al., 2000; Green, 2009; Chaumillon et al., 2010). Most of these estuaries were filled during the Holocene and were subsequently buried by highstand deltaic deposits (Amorosi \& Milli, 2001; Li et al., 2002). Studies on late Holocene delta evolution generally rely upon large amounts of stratigraphic data, being deltaic sediment either exposed or buried at shallow depths (Somoza et al., 1998; Berendsen \& Stouthamer, 2000; Ta et al., 2005; Blum \& Roberts, 2012; Tanabe et al., 2015). Conversely, the deeper, early Holocene transgressive stratigraphy has rarely been investigated in detail (Hijma \& Cohen, 2011; Tanabe et al., 2015; Milli et al., 2016), and stratigraphic correlations are generally based on relatively poor sedimentological and chronological data sets. This work investigated the Late Pleistocene-early Holocene stratigraphy of a $1200 \mathrm{~km}^{2}$ area of the Po coastal plain, correlating 14 newly drilled boreholes, 28 published core descriptions and more than 300 piezocone tests (CPTUs), chronologically constrained with 137 radiocarbon dates; sedimentology, fossil content, geochemistry, stratigraphic evolution and areal distribution of transgressive deposits beneath the Po Plain lowlands were documented. The main purposes of this research are to: (i) reconstruct facies configurations and mechanism of retrogradation of a coastal environment as it evolves during a rapid eustatic rise; (ii) assess the contribution of local factors, such as subsidence, antecedent topography and basin morphology in controlling the shape and the internal architecture of transgressive estuarine deposits; and (iii) test the predictability of depositional facies models on retrogradational systems.

\section{B ACKGROUND}

The Po Plain and the adjacent Adriatic Sea form the Pliocene-Quaternary foreland basin between the Apennines, the southern Alps and the Dinarides (Ori et al., 1986). In a source to sink perspective, the Po Plain, the Adriatic Sea and the surrounding mountain chains constitute a unique, complex system where sediment routing and dispersal is influenced by a wide array of allogenic (climate, eustasy and tectonics) and autogenic (local subsidence, lithology of the drainage areas and coastal dynamics) factors. The stratigraphic architecture of the area investigated in this work results from the combination of all of these factors (Amorosi et al., 1999; Bruno et al., 2017).

\section{The Po drainage system}

The modern Po Plain is bounded to the west and to the north by the Alps and to the south by the Northern Apennines. Crystalline-metamorphic and ophiolite complexes crop out over large parts of the western and central Alps (Fig. 1). Mesozoic carbonate and dolostone rocks are extensively exposed in the eastern Alps (Fig. 1). The Northern Apennines are mainly composed of Cretaceous tectonically deformed clays (the Ligurian units; Codegone et al., 2012; Carlini et al., 2013) and Tertiary turbidites (MarnosoArenacea formation; Ricci Lucchi, 1986; Tinterri \& Tagliaferri, 2015). The Po River drains an area of about $75000 \mathrm{~km}^{2}$ and flows in a west-east direction for $652 \mathrm{~km}$ (Fig. 1), receiving water and sediments from 141 tributaries. The Po River discharge, as measured by the Authority of the Po River Basin at Pontelagoscuro, $90 \mathrm{~km}$ from the river mouth, averages about $1500 \mathrm{~m}^{3} \mathrm{sec}^{-1}$. Suspended sediment delivered to the Adriatic basin by the modern Po River is $13 \times 10^{6} \mathrm{t} \mathrm{year}^{-1}$, about $30 \%$ of the total sediment load (Frignani et al., 2005; Syvitski \& Kettner, 2007). 


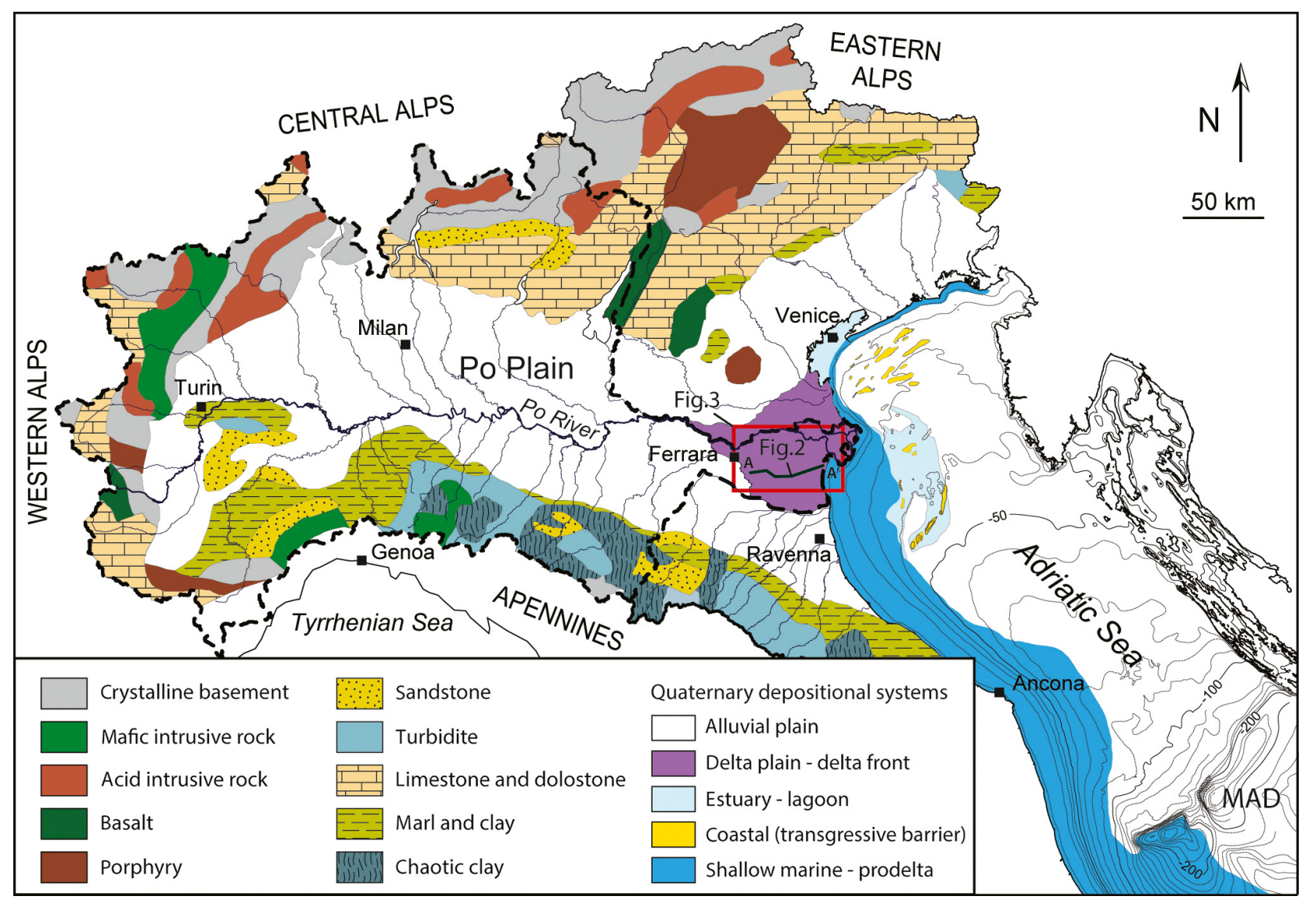

Fig. 1. Geological map of the Po-Adriatic system including: (i) the main rock units cropping out in the Po drainage basin (dashed line) (modified after Amorosi et al., 2002); and (ii) the surficial Quaternary depositional systems of the Po Plain and of the Northern Adriatic (modified after Cattaneo et al., 2003; Moscon et al., 2015). MAD, Mid-Adriatic Depression.

\section{The Adriatic Sea}

The Adriatic Sea is a semi-enclosed epicontinental basin, elongated $800 \mathrm{~km}$ in north-west/ south-east direction. Its northern part is characterized by a shallow continental shelf, gently dipping $c a \quad 0.02^{\circ}$ towards the Mid-Adriatic Depression (MAD), a $260 \mathrm{~m}$ deep basin, located ca $300 \mathrm{~km}$ from the modern Po delta (Fig. 1). The modern Adriatic has a microtidal regime and is storm-dominated. A cyclonic thermohaline circulation causes an overall sediment transport from north to south along the Italian coast (Malanotte Rizzoli \& Bergamasco, 1983; Zavatarelli et al., 1998; Wang \& Pinardi, 2002).

During the LGM ( sea-level was $c a 130 \mathrm{~m}$ lower than at present (Austermann et al., 2013), the northern Adriatic was subaerially exposed and the Po River flowed up to the northern edge of the MAD, where thick progradational deltaic wedges accumulated (Ciabatti et al., 1987; Trincardi et al., 1996).
With the post-glacial sea-level rise, the glacial alluvial plain was progressively flooded, evolving into a broad epicontinental shelf (Trincardi et al., 1994; Correggiari et al., 1996; Cattaneo \& Trincardi, 1999). High rates of eustatic rise, low shelf gradients and low sediment input relative to the increasing accommodation favoured rapid landward shifts of depositional environments. The stepwise nature of sea-level rise permitted the development, during phases of stillstand, of ephemeral barred estuary-lagoon systems, which were drowned and partially reworked during major meltwater pulses (MWP; Storms et al., 2008). As a consequence, physically detached transgressive deposits of different age are encountered along the Adriatic shelf (Cattaneo \& Trincardi, 1999; Cattaneo \& Steel, 2003). In the northern Adriatic, a few tens of kilometres basinward of the Po delta, lagoon-estuary deposits were identified and dated back to about $10 \mathrm{cal}$ kyr вр (Trincardi et al., 1994; Correggiari et al., 1996; Moscon et al., 2015). Adjacent to the 


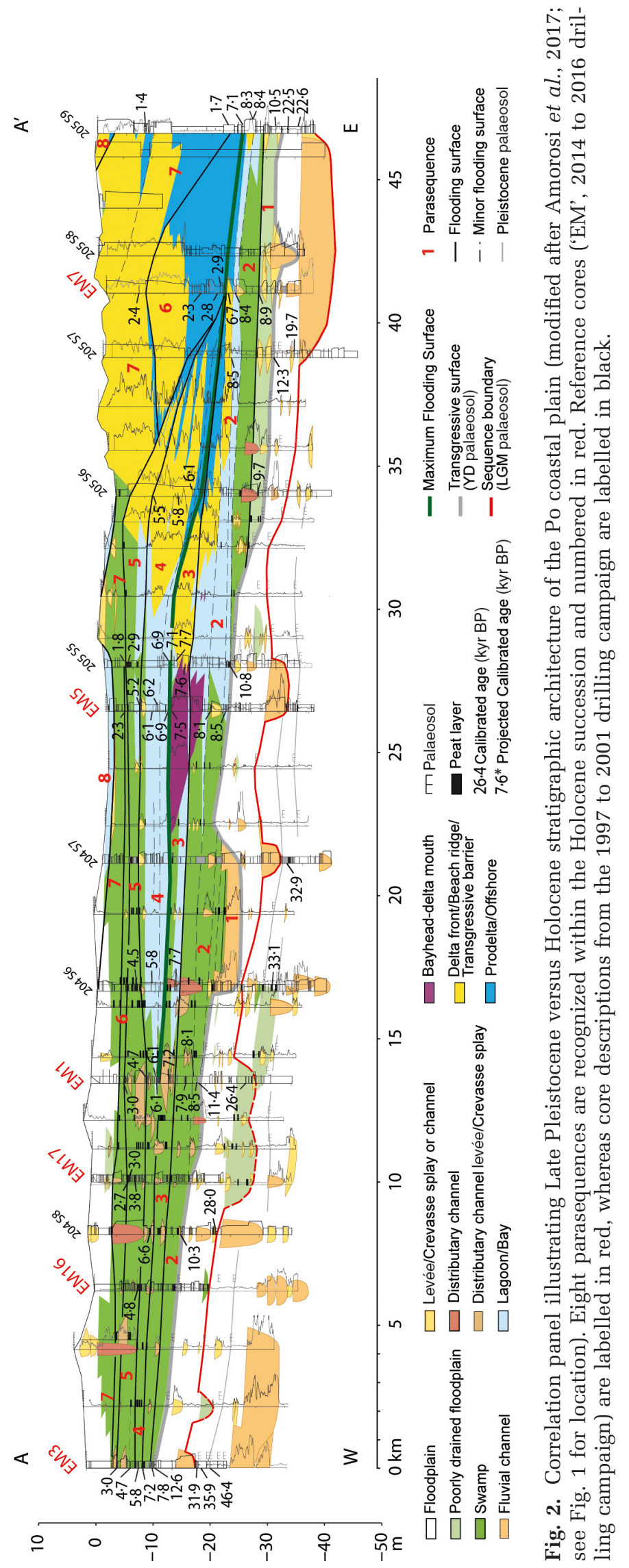




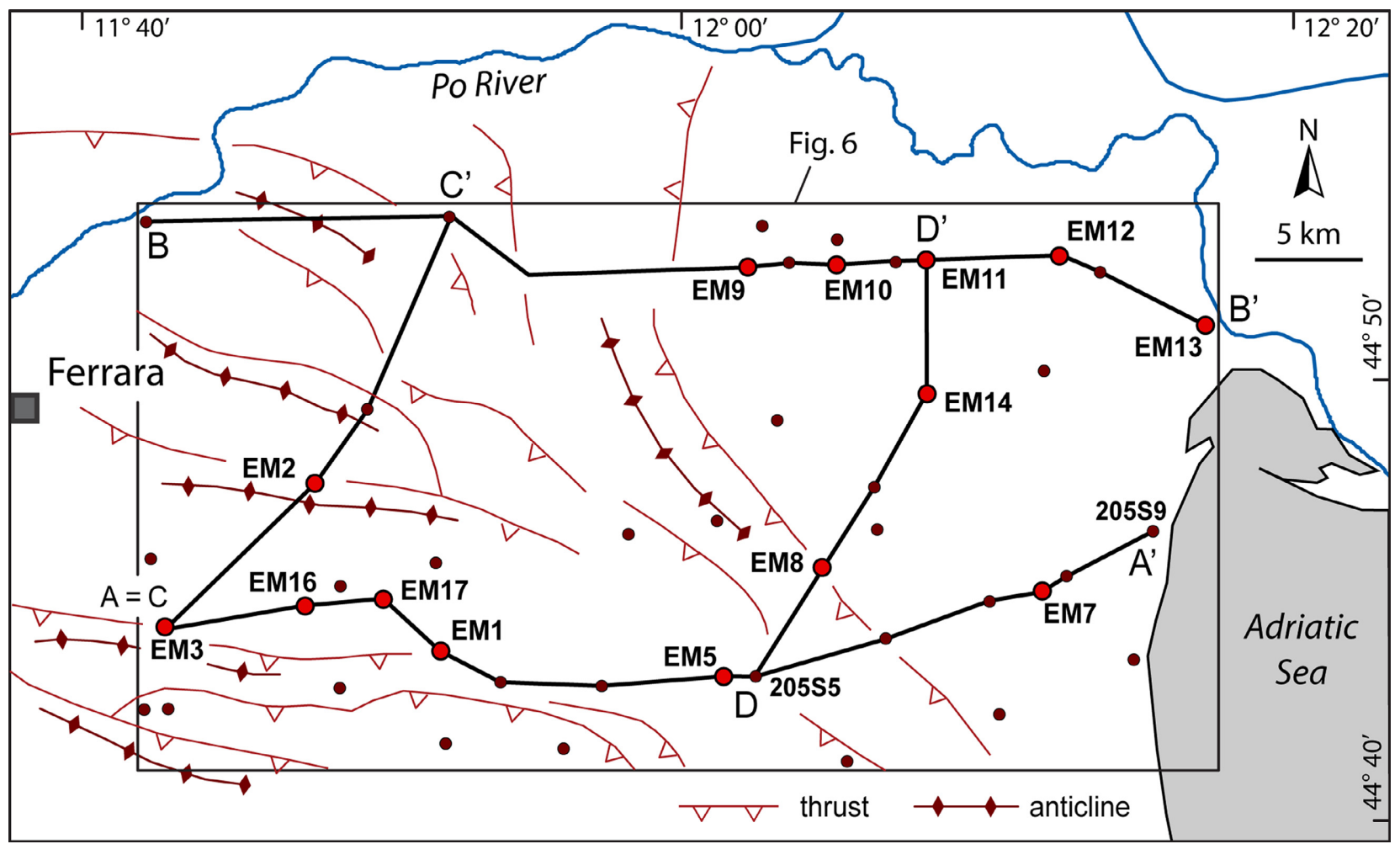

Fig. 3. Location of the study area and of the four cross-sections of Fig. 2 (A A') and Fig. 5 (B B', C C' and D D'). Red filled circles represent the cores recovered during the 2014 to 2016 campaign, whereas dark red dots refer to cores recovered between 1997 and 2001 (CARG project). Buried thrusts and anticlines are from Boccaletti et al. (2011).

Italian coast, transgressive deposits are overlain by highstand prodelta muds (Fig. 1).

\section{Late Quaternary subsurface stratigraphy of the Po Coastal Plain}

The Po Basin fill consists of a shallowingupward succession of Pliocene-Quaternary deposits, up to $8 \mathrm{~km}$ thick (Ricci Lucchi, 1986). The most external deformational fronts of the Apennine chain are covered by this thick package of sediments (Pieri \& Groppi, 1981). The uppermost portion of the Po Basin fill, dated to the last 0.87 Myr (Muttoni et al., 2003), consists almost entirely of alluvial sediments, supplied by the Po River and its tributaries (Amorosi et al., 2008). Beneath the modern coastal plain, the Holocene succession is composed by a wedge-shaped sedimentary body, with maximum thickness of $30 \mathrm{~m}$ (Fig. 2, Amorosi et al., 2017), bounded at the base by a palaeosol dated to about 12.5 to $11.5 \mathrm{kyr}$ вр [Younger Dryas (YD) palaeosol of Amorosi et al., 2016a]. The YD palaeosol is the uppermost of a series of closely spaced, weakly developed palaeosols, formed during the Late Pleistocene. No persistent incised valley was excavated in this phase, owing to high subsidence rates, but shallowly incised ephemeral valleys formed at the MIS $3 / 2$ transition ( $\mathrm{ca} 30 \mathrm{kyr}$ вр) and during the Younger Dryas (Amorosi et al., 2016a). Based on stratal relationships with the overlying deposits, the YD palaeosol has been interpreted as the transgressive surface (TS; Amorosi et al., 2016b), marking the abrupt transition from aggradational to retrogradational facies patterns (Neal \& Abreu, 2009).

The Holocene succession has been recently subdivided into eight millennial-scale parasequences (Fig. 2; Amorosi et al., 2017). Early Holocene parasequences (\#s 1 to 3 ) are stacked in a retrogradational pattern, whereas Middle to Late Holocene parasequences (\#s 4 to 8 ) record a complex pattern of coastal progradation. The maximum flooding surface (MFS), at the turnaround from retrogradation to progradation (Neal \& Abreu, 2009), was dated to about $7 \mathrm{cal} \mathrm{kyr} \mathrm{вP.}$ This article focuses on the stratigraphic architecture of backstepping parasequences 1 to 3 and on their internal anatomy. 
Table 1. List of radiocarbon dates shown in Figs 2 and 5.

\begin{tabular}{|c|c|c|c|c|c|c|c|}
\hline Core & $\begin{array}{l}\text { Sample depth } \\
\text { (m) }\end{array}$ & Lab. & C14 age & $\begin{array}{l}\text { Cal year вр } \\
(2 \sigma \text { range })\end{array}$ & $\begin{array}{l}\text { Cal year вр } \\
\text { (mean value) }\end{array}$ & Dated material & References \\
\hline \multirow[t]{9}{*}{ EM3 } & $5 \cdot 35$ & KIGAM (Korea) & $2870 \pm 40$ & 30802870 & $2975 \pm 105$ & Wood & Amorosi et al. (2016a) \\
\hline & $7 \cdot 65$ & KIGAM & $4180 \pm 30$ & $4770 \quad 4615$ & $4690 \pm 80$ & Wood & Amorosi et al. (2016a) \\
\hline & 9.05 & KIGAM & $5050 \pm 40$ & 59105710 & $5810 \pm 100$ & Plant fragment & Amorosi et al. (2016a) \\
\hline & $9 \cdot 75$ & KIGAM & $6270 \pm 40$ & 72757150 & $7215 \pm 60$ & Wood & Amorosi et al. (2016a) \\
\hline & $11 \cdot 45$ & KIGAM & $6990 \pm 40$ & 79357720 & $7830 \pm 110$ & Plant fragment & Amorosi et al. (2016a) \\
\hline & $11 \cdot 90$ & KIGAM & $10640 \pm 60$ & 1272012525 & $12620 \pm 100$ & Sediment & Amorosi et al. (2016a) \\
\hline & $19 \cdot 35$ & CIRCE (Italy) & $27980 \pm 300$ & 3272031230 & $31980 \pm 750$ & Wood & Amorosi et al. (2016a) \\
\hline & $20 \cdot 05$ & CIRCE & $32000 \pm 220$ & 3637035400 & $35900 \pm 480$ & Sediment & Amorosi et al. (2016a) \\
\hline & $21 \cdot 25$ & CIRCE & $42800 \pm 800$ & $48030 \quad 44720$ & $46370 \pm 1650$ & Sediment & Amorosi et al. (2016a) \\
\hline EM16 & $7 \cdot 50$ & KIGAM & $4220 \pm 40$ & 48604780 & $4820 \pm 40$ & Wood & Amorosi et al. 2017 \\
\hline \multirow[t]{3}{*}{$204 \mathrm{~S} 8$} & $11 \cdot 00$ & ENEA (Italy) & $5750 \pm 80$ & 67406395 & $6570 \pm 170$ & Peat & $\begin{array}{l}\text { CARG Project, Sheet } \\
204\end{array}$ \\
\hline & $16 \cdot 00$ & ENEA & $9050 \pm 85$ & 1042810109 & $10270 \pm 160$ & Peat & $\begin{array}{l}\text { CARG Project, Sheet } \\
204\end{array}$ \\
\hline & $22 \cdot 30$ & ENEA & $23050 \pm 210$ & 2848527460 & $27970 \pm 510$ & Peat & $\begin{array}{l}\text { CARG Project, Sheet } \\
204\end{array}$ \\
\hline \multirow[t]{3}{*}{ EM17 } & $6 \cdot 40$ & KIGAM & $2550 \pm 40$ & 27552675 & $2715 \pm 80$ & Peat & Amorosi et al. 2017 \\
\hline & $6 \cdot 70$ & KIGAM & $2910 \pm 40$ & $3175 \quad 2925$ & $3050 \pm 65$ & Peat & Amorosi et al. 2017 \\
\hline & $8 \cdot 40$ & KIGAM & $3500 \pm 40$ & 38853685 & $3785 \pm 100$ & Peat & Amorosi et al. 2017 \\
\hline \multirow[t]{10}{*}{ EM1 } & $5 \cdot 75$ & KIGAM & $2860 \pm 40$ & 30802860 & $2970 \pm 110$ & Peat & Amorosi et al. 2017 \\
\hline & $9 \cdot 50$ & KIGAM & $4190 \pm 40$ & $4770 \quad 4605$ & $4690 \pm 85$ & Plant fragment & Amorosi et al. 2017 \\
\hline & $11 \cdot 30$ & KIGAM & $5630 \pm 40$ & 62806020 & $6150 \pm 130$ & Shell & Amorosi et al. 2017 \\
\hline & $11 \cdot 40$ & KIGAM & $5340 \pm 40$ & 62155995 & $6105 \pm 110$ & Wood & Amorosi et al. 2017 \\
\hline & $13 \cdot 30$ & KIGAM & $6340 \pm 50$ & 73357165 & $7250 \pm 85$ & Plant fragment & Amorosi et al. 2017 \\
\hline & $16 \cdot 50$ & KIGAM & $7040 \pm 50$ & 79707750 & $7870 \pm 50$ & Peat & Amorosi et al. 2017 \\
\hline & $17 \cdot 85$ & KIGAM & $7340 \pm 50$ & 82258020 & $8125 \pm 125$ & Wood & Amorosi et al. 2017 \\
\hline & $18 \cdot 40$ & KIGAM & $7730 \pm 50$ & 86008410 & $8510 \pm 50$ & Peat & Amorosi et al. 2017 \\
\hline & $18 \cdot 70$ & KIGAM & $9950 \pm 60$ & 1162511235 & $11430 \pm 195$ & Sediment & Amorosi et al. 2017 \\
\hline & $26 \cdot 90$ & KIGAM & $22200 \pm 120$ & 2684026070 & $26450 \pm 390$ & Wood & Amorosi et al. 2017 \\
\hline \multirow[t]{4}{*}{204 S6 } & $6 \cdot 70$ & $\begin{array}{l}\text { ETH } \\
\text { (Switzerland) }\end{array}$ & $4010 \pm 60$ & 46504300 & $4470 \pm 175$ & Peat & Amorosi et al. (2005) \\
\hline & $9 \cdot 60$ & ENEA & $5340 \pm 70$ & 59855655 & $5825 \pm 80$ & Sediment & Amorosi et al. (2005) \\
\hline & $13 \cdot 80$ & ETH & $6895 \pm 65$ & 78607610 & $7735 \pm 170$ & Peat & Amorosi et al. (2005) \\
\hline & $30 \cdot 70$ & ETH & $29030 \pm 330$ & 3391032250 & $33080 \pm 830$ & Peat & $\begin{array}{l}\text { CARG Project, Sheet } \\
204\end{array}$ \\
\hline $204 \mathrm{~S} 7$ & $32 \cdot 30$ & ETH & $28890 \pm 330$ & 3378031990 & $32890 \pm 890$ & Peat & $\begin{array}{l}\text { CARG Project, Sheet } \\
204\end{array}$ \\
\hline \multirow[t]{8}{*}{ EM5 } & $3 \cdot 10$ & KIGAM & $2280 \pm 40$ & 23552300 & $2325 \pm 30$ & Plant fragment & Amorosi et al. 2017 \\
\hline & $5 \cdot 45$ & KIGAM & $4500 \pm 40$ & 53055040 & $5170 \pm 130$ & Plant fragment & Amorosi et al. 2017 \\
\hline & $7 \cdot 70$ & KIGAM & $5550 \pm 40$ & 61905945 & $6080 \pm 65$ & Wood & Amorosi et al. 2017 \\
\hline & $8 \cdot 60$ & KIGAM & $5700 \pm 40$ & 63156175 & $6245 \pm 40$ & Wood & Amorosi et al. 2017 \\
\hline & $10 \cdot 45$ & KIGAM & $6310 \pm 50$ & 71406755 & $6915 \pm 75$ & Wood & Amorosi et al. 2017 \\
\hline & $11 \cdot 20$ & KIGAM & $6560 \pm 50$ & 75707420 & $7500 \pm 40$ & Wood & Amorosi et al. 2017 \\
\hline & $17 \cdot 90$ & KIGAM & $7320 \pm 50$ & 82108010 & $8110 \pm 50$ & Wood & Amorosi et al. 2017 \\
\hline & $20 \cdot 55$ & KIGAM & $7780 \pm 50$ & 86458430 & $8535 \pm 55$ & Wood & Amorosi et al. 2017 \\
\hline \multirow[t]{7}{*}{205 S5 } & $3 \cdot 35$ & KIGAM & $1890 \pm 40$ & 19001720 & $1810 \pm 45$ & Wood & Amorosi et al. 2017 \\
\hline & $4 \cdot 20$ & KIGAM & $2750 \pm 40$ & 29452765 & $2855 \pm 45$ & Plant fragment & Amorosi et al. 2017 \\
\hline & $11 \cdot 25$ & KIGAM & $6260 \pm 50$ & 69856725 & $6850 \pm 65$ & Wood & Amorosi et al. 2017 \\
\hline & $11 \cdot 65$ & KIGAM & $6190 \pm 40$ & 71806975 & $7080 \pm 50$ & Wood & Amorosi et al. 2017 \\
\hline & $12 \cdot 70$ & KIGAM & $6860 \pm 50$ & 77957595 & $7695 \pm 50$ & Plant fragment & Amorosi et al. 2017 \\
\hline & $14 \cdot 00$ & KIGAM & $6690 \pm 50$ & 76557475 & $7565 \pm 45$ & Plant fragment & Amorosi et al. 2017 \\
\hline & $22 \cdot 40$ & ETH & $9445 \pm 85$ & 1109010490 & $10790 \pm 300$ & Wood & Amorosi et al. (2003) \\
\hline \multirow[t]{2}{*}{$205 \mathrm{~S} 6$} & $6 \cdot 55$ & KIGAM & $4990 \pm 40$ & 55905320 & $5480 \pm 70$ & Shell & Amorosi et al. 2017 \\
\hline & $10 \cdot 85$ & KIGAM & $5330 \pm 40$ & 59205720 & $5820 \pm 50$ & Shell & Amorosi et al. 2017 \\
\hline
\end{tabular}


Table 1. (continued)

\begin{tabular}{|c|c|c|c|c|c|c|c|}
\hline Core & $\begin{array}{l}\text { Sample depth } \\
(\mathrm{m})\end{array}$ & Lab. & C14 age & $\begin{array}{l}\text { Cal year вр } \\
\text { ( } 2 \sigma \text { range) }\end{array}$ & $\begin{array}{l}\text { Cal year вр } \\
\text { (mean value) }\end{array}$ & Dated material & References \\
\hline & $13 \cdot 20$ & KIGAM & $5560 \pm 40$ & 62605930 & $6090 \pm 80$ & Shell & Amorosi et al. 2017 \\
\hline & $25 \cdot 00$ & $\begin{array}{l}\text { BETA ANALY- } \\
\text { TIC (USA) }\end{array}$ & $8740 \pm 50$ & 99059555 & $9730 \pm 175$ & Wood & Amorosi et al. (2003) \\
\hline \multirow[t]{3}{*}{205 S7 } & $22 \cdot 70$ & $\begin{array}{l}\text { Keck-CCAMS } \\
\text { (USA) }\end{array}$ & $8180 \pm 30$ & 85888397 & $8500 \pm 95$ & Shell & Scarponi et al. (2013) \\
\hline & $30 \cdot 00$ & ETH & $10450 \pm 100$ & 1259512045 & $12330 \pm 305$ & Wood & Amorosi et al. (2003) \\
\hline & $33 \cdot 70$ & ENEA & $16300 \pm 130$ & 1961019205 & $19685 \pm 350$ & Sediment & Amorosi et al. (2003) \\
\hline \multirow[t]{7}{*}{ EM7 } & $5 \cdot 60$ & KIGAM & $2340 \pm 40$ & 24902305 & $2400 \pm 50$ & Wood & Amorosi et al. 2017 \\
\hline & $16 \cdot 50$ & KIGAM & $2490 \pm 40$ & 23452155 & $2255 \pm 55$ & Shell & Amorosi et al. 2017 \\
\hline & $19 \cdot 35$ & KIGAM & $2910 \pm 40$ & 28652530 & $2790 \pm 35$ & Plant fragment & Amorosi et al. 2017 \\
\hline & $19 \cdot 88$ & KIGAM & $2980 \pm 40$ & 29452760 & $2850 \pm 50$ & Shell & Amorosi et al. 2017 \\
\hline & $21 \cdot 30$ & KIGAM & $6430 \pm 40$ & 68806620 & $6750 \pm 60$ & Shell & Amorosi et al. 2017 \\
\hline & $22 \cdot 40$ & KIGAM & $7540 \pm 50$ & 84258290 & $8355 \pm 35$ & Plant fragment & Amorosi et al. 2017 \\
\hline & $26 \cdot 70$ & KIGAM & $8010 \pm 50$ & 90208700 & $8860 \pm 80$ & Wood & Amorosi et al. 2017 \\
\hline \multirow[t]{8}{*}{205 S9 } & $8 \cdot 40$ & ENEA & $2015 \pm 55$ & 15601260 & $1425 \pm 70$ & Sediment & Amorosi et al. (2003) \\
\hline & 22.74 & KIGAM & $2000 \pm 40$ & 18001570 & $1680 \pm 60$ & Shell & Amorosi et al. 2017 \\
\hline & $25 \cdot 30$ & KIGAM & $6440 \pm 50$ & 72256950 & $7080 \pm 70$ & Shell & Amorosi et al. 2017 \\
\hline & $26 \cdot 95$ & Keck-CCAMS & $7975 \pm 30$ & 83838193 & $8290 \pm 95$ & Shell & Scarponi et al. (2013) \\
\hline & $26 \cdot 95$ & Keck-CCAMS & $8075 \pm 30$ & 85028318 & $8410 \pm 90$ & Shell & Scarponi et al. (2013) \\
\hline & $31 \cdot 20$ & ETH & $9500 \pm 80$ & 1071910294 & $10500 \pm 210$ & Sediment & Amorosi et al. (2003) \\
\hline & $33 \cdot 30$ & ЕTH & $18860 \pm 190$ & 2304022090 & $22550 \pm 430$ & Sediment & Amorosi et al. (2003) \\
\hline & $35 \cdot 60$ & ETH & $18830 \pm 140$ & 2298022120 & $22565 \pm 475$ & Wood & Amorosi et al. (2003) \\
\hline \multirow[t]{3}{*}{ 186050P501 } & $15 \cdot 30$ & ENEA & $1410 \pm 70$ & 14201220 & $1320 \pm 100$ & Sediment & Amorosi et al. (2016a) \\
\hline & $22 \cdot 80$ & ENEA & $6350 \pm 50$ & $7340 \quad 7130$ & $7235 \pm 105$ & Peat & Amorosi et al. (2016a) \\
\hline & $29 \cdot 00$ & ENEA & $9560 \pm 60$ & 1114010700 & $10920 \pm 220$ & Sediment & Amorosi et al. (2016a) \\
\hline \multirow[t]{2}{*}{ 186060P501 } & $9 \cdot 50$ & ENEA & $4400 \pm 60$ & 50804850 & $4965 \pm 115$ & Sediment & Amorosi et al. (2016a) \\
\hline & $16 \cdot 00$ & ENEA & $7640 \pm 80$ & 85958320 & $8455 \pm 140$ & Sediment & Amorosi et al. (2016a) \\
\hline 186020P503 & $43 \cdot 60$ & ENEA & $26100 \pm 200$ & 3084029780 & $30300 \pm 530$ & Sediment & Amorosi et al. (2016a) \\
\hline \multirow[t]{3}{*}{ P8 } & 9.80 & KIGAM & $6020 \pm 50$ & $6990 \quad 6740$ & $6860 \pm 120$ & Wood & Amorosi et al. (2016a) \\
\hline & $13 \cdot 30$ & ENEA & $6550 \pm 90$ & 75857290 & $7435 \pm 150$ & Peat & Amorosi et al. (2016a) \\
\hline & $16 \cdot 10$ & ENEA & $6850 \pm 120$ & 79357510 & $7720 \pm 210$ & Peat & Amorosi et al. (2016a) \\
\hline \multirow[t]{7}{*}{ EM9 } & $6 \cdot 40$ & KIGAM & $4760 \pm 40$ & 55805320 & $5500 \pm 70$ & Wood & Amorosi et al. 2017 \\
\hline & $7 \cdot 85$ & KIGAM & $5790 \pm 40$ & 67206480 & $6590 \pm 50$ & Wood & Amorosi et al. 2017 \\
\hline & $10 \cdot 40$ & KIGAM & $6000 \pm 40$ & 69506740 & $6840 \pm 50$ & Wood & Amorosi et al. 2017 \\
\hline & $14 \cdot 10$ & KIGAM & $6620 \pm 40$ & $7570 \quad 7440$ & $7510 \pm 40$ & Peat & Amorosi et al. 2017 \\
\hline & $15 \cdot 35$ & KIGAM & $7190 \pm 40$ & 81607930 & $8010 \pm 50$ & Peat & Amorosi et al. 2017 \\
\hline & $19 \cdot 05$ & KIGAM & $8290 \pm 50$ & 94409120 & $9290 \pm 90$ & Peat & Amorosi et al. 2017 \\
\hline & $20 \cdot 75$ & KIGAM & $8820 \pm 50$ & 101609680 & $9900 \pm 130$ & Wood & Amorosi et al. 2017 \\
\hline \multirow[t]{7}{*}{ Mezzogoro3 } & 0.90 & $\begin{array}{l}\text { LA SAPIENZA } \\
\text { (Italy) }\end{array}$ & $1620 \pm 65$ & 16351370 & $1500 \pm 130$ & Sediment & $\begin{array}{l}\text { CARG Project, Sheet } \\
187\end{array}$ \\
\hline & 1.90 & LA SAPIENZA & $3300 \pm 60$ & 36453395 & $3520 \pm 125$ & Plant fragment & $\begin{array}{l}\text { CARG Project, Sheet } \\
187\end{array}$ \\
\hline & $5 \cdot 86$ & LA SAPIENZA & $4990 \pm 65$ & 56605330 & $5530 \pm 70$ & Peat & $\begin{array}{l}\text { CARG Project, Sheet } \\
187\end{array}$ \\
\hline & $6 \cdot 40$ & LA SAPIENZA & $5300 \pm 70$ & 60005660 & $5885 \pm 85$ & Peat & $\begin{array}{l}\text { CARG Project, Sheet } \\
187\end{array}$ \\
\hline & $9 \cdot 25$ & LA SAPIENZA & $6350 \pm 70$ & 74307155 & $7290 \pm 140$ & Plant fragment & $\begin{array}{l}\text { CARG Project, Sheet } \\
187\end{array}$ \\
\hline & $14 \cdot 70$ & LA SAPIENZA & $7800 \pm 80$ & 87908410 & $8600 \pm 190$ & Plant fragment & $\begin{array}{l}\text { CARG Project, Sheet } \\
187\end{array}$ \\
\hline & $17 \cdot 40$ & LA SAPIENZA & $8250 \pm 80$ & 94309025 & $9230 \pm 200$ & Peat & $\begin{array}{l}\text { CARG Project, Sheet } \\
187\end{array}$ \\
\hline \multirow[t]{3}{*}{ EM10 } & $2 \cdot 55$ & KIGAM & $2790 \pm 40$ & 30002780 & $2890 \pm 50$ & Wood & Amorosi et al. 2017 \\
\hline & $5 \cdot 45$ & KIGAM & $4460 \pm 40$ & $4860 \quad 4630$ & $4770 \pm 70$ & Shell & Amorosi et al. 2017 \\
\hline & $7 \cdot 00$ & KIGAM & $4700 \pm 40$ & 55905310 & $5430 \pm 80$ & Peat & Amorosi et al. 2017 \\
\hline
\end{tabular}


Table 1. (continued)

\begin{tabular}{|c|c|c|c|c|c|c|c|}
\hline Core & $\begin{array}{l}\text { Sample depth } \\
(\mathrm{m})\end{array}$ & Lab. & C14 age & $\begin{array}{l}\text { Cal year вр } \\
(2 \sigma \text { range })\end{array}$ & $\begin{array}{l}\text { Cal year вр } \\
\text { (mean value) }\end{array}$ & Dated material & References \\
\hline & $8 \cdot 20$ & KIGAM & $5580 \pm 40$ & 64406290 & $6360 \pm 40$ & Wood & Amorosi et al. 2017 \\
\hline \multirow[t]{5}{*}{ Mezzogoro2 } & $6 \cdot 65$ & LA SAPIENZA & $4590 \pm 60$ & 54705210 & $5275 \pm 130$ & Plant fragment & $\begin{array}{l}\text { CARG Project, Sheet } \\
187\end{array}$ \\
\hline & $7 \cdot 30$ & LA SAPIENZA & $4930 \pm 60$ & 57755580 & $5680 \pm 70$ & Plant fragment & $\begin{array}{l}\text { CARG Project, Sheet } \\
187\end{array}$ \\
\hline & $14 \cdot 88$ & LA SAPIENZA & $7640 \pm 70$ & 85858345 & $8450 \pm 60$ & Plant fragment & $\begin{array}{l}\text { CARG Project, Sheet } \\
187\end{array}$ \\
\hline & 14.95 & LA SAPIENZA & $7650 \pm 70$ & 85908355 & $8460 \pm 60$ & Plant fragment & $\begin{array}{l}\text { CARG Project, Sheet } \\
187\end{array}$ \\
\hline & $18 \cdot 45$ & LA SAPIENZA & $7720 \pm 70$ & 82057950 & $8090 \pm 70$ & Peat & $\begin{array}{l}\text { CARG Project, Sheet } \\
187\end{array}$ \\
\hline \multirow[t]{8}{*}{ EM11 } & $3 \cdot 60$ & KIGAM & $3780 \pm 40$ & 43003990 & $4160 \pm 70$ & Shell & Amorosi et al. 2017 \\
\hline & $7 \cdot 50$ & KIGAM & $4410 \pm 40$ & 48304580 & $4720 \pm 70$ & Shell & Amorosi et al. 2017 \\
\hline & $15 \cdot 90$ & KIGAM & $6780 \pm 50$ & 77107560 & $7630 \pm 40$ & Wood & Amorosi et al. 2017 \\
\hline & $17 \cdot 50$ & KIGAM & $7210 \pm 50$ & 79307680 & $7790 \pm 60$ & Shell & Amorosi et al. 2017 \\
\hline & $21 \cdot 70$ & KIGAM & $8380 \pm 50$ & 95009270 & $9400 \pm 60$ & Peat & Amorosi et al. 2017 \\
\hline & $24 \cdot 58$ & KIGAM & $8870 \pm 50$ & 101809765 & $9990 \pm 100$ & Peat & Amorosi et al. 2017 \\
\hline & $24 \cdot 65$ & KIGAM & $9480 \pm 50$ & 1107010580 & $10780 \pm 140$ & Sediment & Amorosi et al. 2017 \\
\hline & $27 \cdot 25$ & KIGAM & $9950 \pm 50$ & 1161511240 & $11400 \pm 110$ & Peat & Amorosi et al. 2017 \\
\hline \multirow[t]{5}{*}{ EM12 } & $5 \cdot 10$ & KIGAM & $1760 \pm 30$ & 17801565 & $1670 \pm 45$ & Wood & Amorosi et al. 2017 \\
\hline & $11 \cdot 80$ & KIGAM & $2130 \pm 40$ & 19301720 & $1830 \pm 50$ & Shell & Amorosi et al. 2017 \\
\hline & $17 \cdot 80$ & KIGAM & $2960 \pm 40$ & 27202400 & $2570 \pm 80$ & Shell & Amorosi et al. 2017 \\
\hline & $18 \cdot 60$ & KIGAM & $2680 \pm 30$ & 28502750 & $2800 \pm 30$ & Shell & Amorosi et al. 2017 \\
\hline & $19 \cdot 90$ & KIGAM & $3300 \pm 40$ & $3635 \quad 3445$ & $3525 \pm 50$ & Wood & Amorosi et al. 2017 \\
\hline \multirow[t]{6}{*}{ EM13 } & $10 \cdot 90$ & KIGAM & $840 \pm 40$ & 650510 & $580 \pm 40$ & Shell & Amorosi et al. 2017 \\
\hline & $17 \cdot 50$ & KIGAM & $1060 \pm 30$ & 1055925 & $975 \pm 35$ & Wood & Amorosi et al. 2017 \\
\hline & $22 \cdot 65$ & KIGAM & $1900 \pm 40$ & 17001420 & $1570 \pm 50$ & Shell & Amorosi et al. 2017 \\
\hline & $26 \cdot 75$ & KIGAM & $8040 \pm 50$ & 90908715 & $8900 \pm 100$ & Wood & Amorosi et al. 2017 \\
\hline & $29 \cdot 00$ & KIGAM & $8500 \pm 50$ & 95459440 & $9500 \pm 30$ & Peat & Amorosi et al. 2017 \\
\hline & $32 \cdot 00$ & KIGAM & $9080 \pm 50$ & 1038510175 & $10250 \pm 50$ & Wood & Amorosi et al. 2017 \\
\hline \multirow[t]{9}{*}{ EM2 } & $3 \cdot 20$ & KIGAM & $1180 \pm 40$ & 1185980 & $1085 \pm 100$ & Wood & Amorosi et al. (2016a) \\
\hline & $6 \cdot 45$ & KIGAM & $3110 \pm 80$ & 34853075 & $3280 \pm 200$ & Plant fragment & Amorosi et al. (2016a) \\
\hline & $11 \cdot 10$ & KIGAM & $4680 \pm 40$ & 54805315 & $5395 \pm 80$ & Plant fragment & Amorosi et al. (2016a) \\
\hline & $13 \cdot 35$ & KIGAM & $6840 \pm 40$ & 77607590 & $7675 \pm 85$ & Plant fragment & Amorosi et al. (2016a) \\
\hline & $15 \cdot 20$ & KIGAM & $7460 \pm 40$ & 83658190 & $8280 \pm 50$ & Plant fragment & Amorosi et al. (2016a) \\
\hline & $20 \cdot 55$ & KIGAM & $7470 \pm 50$ & 83808190 & $8285 \pm 95$ & Wood & Amorosi et al. (2016a) \\
\hline & $22 \cdot 90$ & KIGAM & $8320 \pm 50$ & 94709200 & $9335 \pm 135$ & Wood & Amorosi et al. (2016a) \\
\hline & $24 \cdot 50$ & KIGAM & $9990 \pm 50$ & 1165011260 & $11450 \pm 195$ & Plant fragment & Amorosi et al. (2016a) \\
\hline & $25 \cdot 45$ & KIGAM & $11110 \pm 50$ & 1308012820 & $12950 \pm 130$ & Plant fragment & Amorosi et al. (2016a) \\
\hline \multirow[t]{3}{*}{ EM8 } & $5 \cdot 45$ & KIGAM & $4890 \pm 50$ & $5740 \quad 5480$ & $5630 \pm 50$ & Peat & This article \\
\hline & $7 \cdot 30$ & KIGAM & $5800 \pm 40$ & 67206480 & $6600 \pm 50$ & Wood & This article \\
\hline & $22 \cdot 40$ & KIGAM & $7950 \pm 40$ & 88908640 & $8820 \pm 100$ & Wood & This article \\
\hline \multirow[t]{5}{*}{ EM14 } & $5 \cdot 25$ & KIGAM & $4230 \pm 40$ & 48704620 & $4760 \pm 70$ & Wood & This article \\
\hline & $6 \cdot 15$ & KIGAM & $4960 \pm 40$ & 58605600 & $5690 \pm 60$ & Wood & This article \\
\hline & $8 \cdot 90$ & KIGAM & $5150 \pm 40$ & 60005750 & $5890 \pm 70$ & Peat & This article \\
\hline & $17 \cdot 95$ & KIGAM & $7590 \pm 50$ & 85208320 & $8420 \pm 40$ & Peat & This article \\
\hline & $19 \cdot 10$ & KIGAM & $7710 \pm 50$ & 85908410 & $8490 \pm 50$ & Peat & This article \\
\hline
\end{tabular}

\section{METHODS}

A data set of 14 continuously cored boreholes, 28 published core descriptions and 308 piezocone tests (CPTUs) was used to investigate an area south of the modern Po River (Fig. 3). Data density ( $c a 3.5$ data $\mathrm{km}^{-2}$ ) dramatically decreases north of the Po River, preventing reliable palaeoenvironmental reconstructions.

Fourteen cores ('EM' cores in Figs 2 and 3), recovered between 2014 and 2016, as part of a collaborative research project supported by ExxonMobil Upstream Research Company, were used for detailed facies characterization. Core 
descriptions referring to boreholes drilled between 1997 and 2001, as part of the Geological Mapping Project of Italy (CARG) at a scale of $1: 50$ 000, were reinterpreted following calibration with the new cores. Piezocone tests were used to improve data coverage and map the three-dimensional distribution of facies. Their interpretation was based on Amorosi \& Marchi (1999), following calibration with adjacent cores.

Seventy-four samples, including soil, peat, vegetal remains, wood fragments and mollusc shells, were collected for AMS radiocarbon dating (Table 1). All samples were cleaned with deionized water and dried in a $40^{\circ} \mathrm{C}$ oven. The samples were analysed at KIGAM Laboratory (Daejeon, Republic of Korea), after acid-alkaliacid pretreatment. Conventional ${ }^{14} \mathrm{C}$ ages were calibrated using OxCal 4.2 (Bronk Ramsey, 2009) with the IntCal 13 and Marine13 curves (Reimer et al., 2013).

In order to support and refine the palaeoenvironmental characterization of sedimentary facies, 50 samples of bulk sediment ( $c a 550 \mathrm{~cm}^{3}$ of cored sediment) were collected from selected EM cores for palaeontological analyses (molluscs, ostracods and benthic foraminifera). For sediment provenance reconstructions, total metal concentrations of 38 samples were analysed by X-ray fluorescence (XRF) at Bologna University laboratories. The $\mathrm{Cr} / \mathrm{Al}_{2} \mathrm{O}_{3}$ ratio has been tested successfully for the discrimination of Apennine versus Po River sediment supply (Amorosi et al., 2002, 2014a). Because dolomite represents a mineralogical marker for Alpine provenance in the Holocene succession of the Po Plain (Marchesini et al., 2000), the $\mathrm{Mg} / \mathrm{Al}_{2} \mathrm{O}_{3}$ ratio was used to differentiate local sediment contribution from Alpine sources.

Fourteen cores, 28 core logs, 18 well logs and 68 CPTUs were plotted on four stratigraphic panels, where facies correlations were carried out based on geometric criteria and constrained by radiocarbon data. Key stratigraphic surfaces (palaeosols and flooding surfaces) were used as the basis for stratigraphic correlation. Stratigraphic data away from the section traces were analysed and interpreted with the 3D software Petrel $^{\circledR}$, in order to support palaeogeographic mapping.

\section{SEDIMENTARY FACIES}

The facies associations identified in this work belong to four depositional systems: alluvial, estuarine, deltaic and nearshore. Because this work focuses on the Early Holocene evolution of the Po coastal plain, Late Holocene deltaic deposits are not considered in this article. The reader is referred to previous works (Amorosi et al., 1999, 2003) for detailed descriptions.

\section{Alluvial depositional system}

Facies A1: Fining-upward coarse to medium sand (fluvial-channel facies association)

Description. This facies association consists of coarse to medium grey sands grading upward into fine to silty sands (Fig. 4A), with subordinate centimetre-thick silt intercalations. Organic-matter-rich clays cap the fining-upward succession. The base is erosional. Vegetal remains were seldom observed. Macroinvertebrate fossils are sparse and represented by freshwater gastropod shells and opercula (for example, Bithynia). Meiofauna is absent or includes few, poorly preserved planktonic foraminifera. In CPTU tests, this facies association shows high tip-resistance values $\left(q_{\mathrm{c}}>3 \mathrm{MPa}\right)$, generally decreasing upward and negative pore pressure $(u)$. This facies association is commonly encountered in the northern part of the study area, generally at depths $>25 \mathrm{~m}$. Its thickness locally exceeds $10 \mathrm{~m}$ and sediment composition reflects provenance from the Po drainage area. Sands from southern cores (EM3, EM5 and EM7; Figs 2 and 3) are generally finer-grained (from medium to very fine) and $<4 \mathrm{~m}$ thick. Tip-resistance values are between $3 \mathrm{MPa}$ and $20 \mathrm{MPa}$. Sediment composition indicates provenance from the Northern Apennines.

Interpretation. Sedimentological characteristics and the presence of reworked freshwater macrofossils allow interpretation of this facies association as fluvial-channel deposits. Decreasing-upward $q_{\mathrm{c}}$ values reflect the fining-upward grain-size trend, whereas negative $u$ values indicate high permeability. The transition to overlying muds is likely to reflect channel abandonment. Differences in grain size and thickness between northern and southern sand bodies probably reflect the different size of the drainage basins (Blum et al., 2013). Thick sand bodies were supplied by the Po River, whose mountainous drainage area nowadays exceeds $30000 \mathrm{~km}^{2}$. Conversely, the thinner and finer sand bodies were fed by Apennine rivers, which drained areas typically $<5000 \mathrm{~km}^{2}$. 


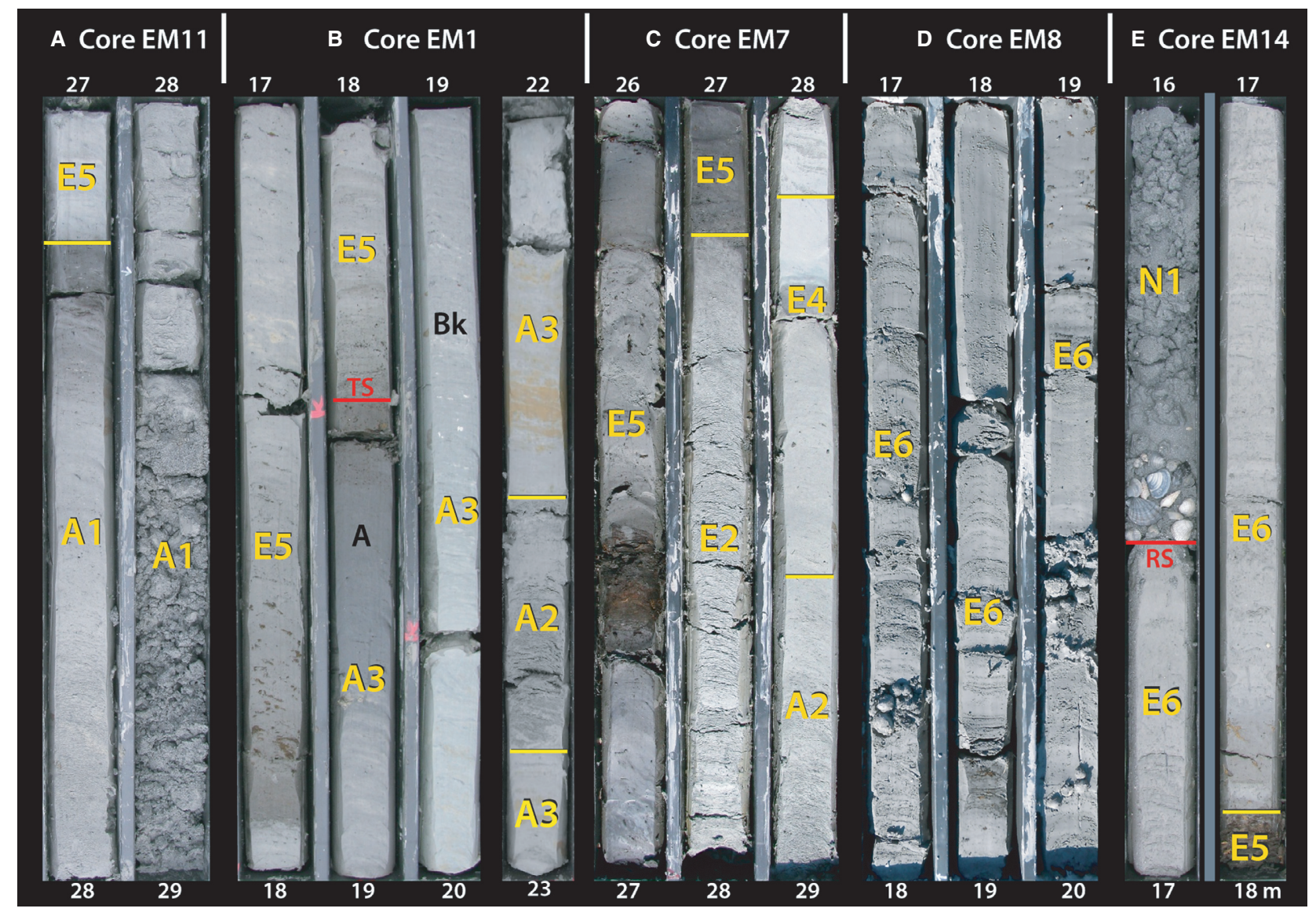

Fig. 4. Representative core photographs of the major facies association identified in the studied cores. Core bottom is lower right corner. Core length is $1 \mathrm{~m}$. (A) Fining-upward fluvial-channel sands capped by organic-matterrich clays. (B) Late Pleistocene pedogenized silts and clays overlain by soft inner-estuary clays. (C) Upward transition from poorly drained to inner-estuary facies. (D) Shell-rich, outer-estuary deposits. (E) Lag of reworked marine and brackish shells at the base of transgressive-barrier sands. TS, transgressive surface; RS, ravinement surface.

Facies A2: Fine to silty sand and sand-silt alternations (crevasse and levée facies association)

Description. This facies association, up to $2 \mathrm{~m}$ thick, includes two facies. Facies A2a consists of fine to silty sands with either a fining-upward or coarsening-upward trend. Fining-upward sands have a sharp base and gradational top (Fig. 4B). Coarsening-upward sands have a gradational base and sharp top. Tip resistance is $<10 \mathrm{MPa}$. Pore pressure is negative or $<u_{0}$ (static equilibrium pore pressure). Facies A2b consists of centimetre-scale alternations of fine and silty sands with silty clays. Sand layers have a sharp base and grade into overlying muds. Vegetal remains, root traces and carbonate concretions are rarely encountered within the clayey intervals. In CPTU tests, sand/mud alternations have variable $q_{\mathrm{c}}$ and $u$ values. Tip resistance fluctuates between about $2 \mathrm{MPa}$ and $10 \mathrm{MPa}$, pore pressure between $<0$ and $>u_{0}$. Both facies may be transitional to facies association A1. The colour is grey or brown, with occasional mottles given by $\mathrm{Fe}$ oxides. Invertebrate fossils are rare and represented by opercula or unidentifiable fragments. A few fragments of freshwater ostracods (Candona and Ilyocypris) and poorly preserved marine foraminifera were rarely found.

Interpretation. Stratigraphic relationships of this facies association with A1 denote a close relation with fluvial activity. Facies A2a (sand bodies with internal coarsening-upward trend) is interpreted as the result of crevassing of fluvial levée and subsequent spreading of the suspended load in wide splays. Sand bodies with internal fining-upward trend were most likely to be crevasse channels within which the bedload 
was conveyed. Sand-mud alternations of facies A2b are interpreted as being the result of multiple overflow events, adjacent to fluvial channels (natural levées). Crevasse splays and channel levées formed topographically elevated areas that were subaerially exposed for prolonged periods, as confirmed by oxidation traces and $\mathrm{CaCO}_{3}$ concretions.

Facies A3: Varicoloured and hardened silt and clay (well-drained floodplain facies association)

Description. This facies association consists of a monotonous succession, up to $7 \mathrm{~m}$ thick, of clayey silt and silty clay. Consistency is generally high, with pocket penetration (PP) values invariably $>2 \mathrm{~kg} \mathrm{~cm}^{-2}$. Meiofauna specimens were not encountered. Pulmonate gastropods (for example, Cernuella spp.) are locally encountered. The colour varies from light-grey green $(2 \cdot 5 \mathrm{Y} \quad 7 / 3)$ to dark-grey (5Y 5/1), with yellowish mottles given by Fe oxides (Fig. 4B). Dark horizons, up to $1 \mathrm{~m}$ thick, show no reaction to $\mathrm{HCl}$, have high PP values $\left(>3 \mathrm{~kg} \mathrm{~cm}^{-2}\right)$ and overlie light-grey (2.5Y 8/1) clayey silts ( $\mathrm{PP}$ values $>5 \mathrm{~kg} \mathrm{~cm}{ }^{-2}$ ), rich in carbonate concretions. The latter can be coalescent nodules, or less frequently coatings and filaments along root traces. Reaction to $\mathrm{HCl}$ is strong, even where concretions are not detectable through simple visual inspection. The CPTU tests yielded $q_{\mathrm{c}}$ values of 1 to $3 \mathrm{MPa}$. Lateral friction $\left(f_{\mathrm{s}}\right)$, in the range of 50 to $100 \mathrm{kPa}$, increases up to $150 \mathrm{kPa}$ at the transition from dark-grey horizons to the underlying carbonate-rich muds. At the same stratigraphic levels, pore pressure, generally $\gg u_{0}$, may drop down to negative values. This facies association is generally encountered at depths $>10 \mathrm{~m}$ in the southern part of the study area, where it attains the maximum thickness.

Interpretation. The dominance of fine-grained material suggests deposition in a floodplain environment. Horizonation, given by colour and calcite distribution along the vertical profile, is related to pedogenic processes. In particular, couplets with carbonate-free, dark horizons above calcic horizons, are interpreted as A-Bk profiles of weakly developed palaeosols (Inceptisols of Soil Survey Staff, 1999). The dark colour results from the accumulation and decomposition of organic material (A horizon). Carbonates were leached from the topsoil and accumulated few decimetres below, in the Bk horizon. The morphology of pedogenic calcite (evolutionary stages II-III of Gile et al., 1981; Machette, 1985) suggests periods of subaerial exposure on the order of a few thousand years. This estimate is substantiated by radiocarbon dates from similar soil profiles observed at the Po Basin margin (Amorosi et al., 2014c). Carbonate redistribution and oxidation, requiring the presence of a vadose zone, indicate low groundwater table during subaerial exposure. The accumulation of secondary calcite in the Bk horizons results in higher consistency, as highlighted by pocket and cone penetration tests. High $u$ values reflect low permeability, typical of fine-grained materials. The local drop to negative values may be ascribable to microfracturing provoked by pedogenic processes or by the brittle response of overconsolidated material to penetration.

\section{Wave-dominated estuarine depositional system}

Facies E1: Fining-upward coarse to fine sands (bayhead-delta plain distributary channel)

Description. This facies association consists of fining-upward, coarse to fine, grey sands, with an erosional base and gradational top. Macrofaunal remains comparable to those of facies A1 were observed. Vegetal remains, wood fragments and reworked freshwater to oligo-mesohaline ostracods (fragments belonging to genera Candona and Pseudocandona) are scattered throughout the whole interval. Suites of macrofaunal remains comparable with facies A1 were observed. Cone penetration values $\left(3<q_{\mathrm{c}}<20 \mathrm{MPa}\right)$ generally decrease upward. Pore pressure is negative. Three main characteristics allow distinction of this facies association from A1: (i) lower thickness, in the range of 2 to $8 \mathrm{~m}$; (ii) width typically less than mean data spacing (i.e. $1400 \mathrm{~m}$ ); and (iii) lateral transition to organic-matter-rich clays.

Interpretation. Coarse to fine sands, with erosive base and fining-upward trend, are interpreted as formed in active channels. Given the small width and transition to organic-matter-rich clays, these sand bodies are interpreted as distributary-channel deposits (Bhattacharya, 2006). Their variable thickness is likely to reflect different orders of bifurcation of the trunk channel, with thickness decreasing downdip with increasing bifurcation order (Olariu \& Bhattacharya, 2006). The rare occurrence of fragments of freshwater to low-brackish taxa is consistent with this facies interpretation. 
Facies E2: Medium to silty grey sand and sand-silt alternation (bayhead-delta plain crevasse facies association)

Description. This facies association, laterally contiguous to facies E1, shares several sedimentological characteristics with facies association A2, including lithology, grain-size tendencies, thickness, accessory material and CPTU values.

Interpretation. Based on its sedimentological characteristics, this facies association is interpreted, like facies A2, as the result of crevassing and overflow. It is included in the estuarine depositional system, based on its stratigraphic position, close to facies E1.

\section{Facies E3: Coarsening-upward fine to coarse} sand (bayhead-delta mouth facies association) Description. Facies association E3, up to $4 \mathrm{~m}$ thick, is composed of grey, fine to coarse sands, with typical coarsening-upward trend. The base is either sharp or erosional, whereas the top is sharp. Penetration values are in the same range as facies E1. Pore pressure is negative. Vegetal remains and wood fragments are locally encountered at the top. Macrofossils include reworked freshwater taxa, along with brackish (thinshelled Cerastoderma glaucum) to nearshore molluscs. A scarce, poorly preserved ostracod fauna, entirely composed of the euryhaline species Cyprideis torosa, is encountered. At places, a few valves of freshwater ostracods (Ilyocypris spp.) and poorly preserved specimens of Ammonia tepida are also found.

Interpretation. Based on sedimentological characteristics and on the fossil content, facies E3 is interpreted as bayhead-delta mouth. The coarsening-upward trend indicates progradation (Coleman \& Wright, 1975; Elliott, 1986; Schwarz et al., 2011). The presence of brackish to nearshore fossil taxa (Dalrymple et al., 1992), accompanied by a freshwater fauna, is consistent with an estuarine environment subject to fluvial input (Hijma et al., 2009).

\section{Facies E4: Soft grey silt and clay (poorly} drained flood basin)

Description. Facies association E4 (Fig. 4C) is dominated by soft, grey silt and clay, with faint lamination that reflects millimetre-scale clay-silt alternations. Vegetal remains are frequently observed. Clays are softer than in facies A3 $\left(\mathrm{PP}=1.2\right.$ to $1.8 \mathrm{~kg} \mathrm{~cm}^{-2} ; q_{\mathrm{c}}=0.8$ to $\left.1.2 \mathrm{MPa}\right)$ and have no horizonation, nor traces of oxidation. Diagnostic invertebrate fossils were not found. This facies association was encountered in the south-eastern part of the study area, above facies association A3 (Fig. 2).

Interpretation. The dominance of fine-grained material suggests deposition in a distal environment. Clay-silt alternation at the millimetrescale testifies to multiple overflow events. The absence of fossils suggests that the sediment source is mainly fluvial. Poor consistency and lack of horizonation or oxidation indicate the lack of a stable vadose zone (groundwater table a few centimetres below the topographic surface), typical of a poorly drained flood basin.

Facies E5: Organic-matter-rich soft clay and peat (inner-estuary/swamp)

Description. Facies association E5 consists of a 2 to $6 \mathrm{~m}$ thick succession of very soft, grey and dark-grey clays, with subordinate, millimetrethick, silt and silty sand intercalations. Local accumulation of well-preserved organic material, including vegetal remains and wood fragments, was frequently observed (Fig. 4B). Peat layers, up to $60 \mathrm{~cm}$ thick, occur at various stratigraphic levels (Fig. 4C). A freshwater oligotypic mollusc fauna mainly consisting of Pisidium and/or hydrobiids species can be encountered. In cores EM7 and 205S5, an abundant, well-preserved ostracod fauna, mainly composed of freshwateroligohaline species (Darwinula stevensoni and Cytheromorpha fuscata), was recovered. In core EM2, no ostracods were found. No traces of oxidation were observed. Pocket penetration tests yielded very low values $\left(<1.2 \mathrm{~kg} \mathrm{~cm}^{-2}\right)$. Cone resistance curves have linear shape, with $q_{\mathrm{c}}$ values $<0.8 \mathrm{MPa}$. Pore pressure is $>u_{\mathrm{O}}$ and increases linearly with depth. This facies association is pervasive in the study area, especially in the innermost segment.

Interpretation. Based on lithology, consistency, accessory material and fossil content, this facies association is interpreted to have been deposited in low-lying areas with permanent stagnant waters (i.e. water table above the topographic surface). Thick successions of clays, with rare coarser beds, reflect sporadic overbank deposition away from an active channel. Lack of traces of oxidation is consistent with waterlogging and reducing conditions. Peat layers probably accumulated in swamp environments (rheotrophic 
mires), relatively starved from regular sedimentary input (Miola et al., 2006; Hijma \& Cohen, 2011; Ishii et al., 2016). Given its thickness and lateral extent of tens of kilometres, this facies association is interpreted as the inner portion of a wider estuarine environment. The freshwaterlow-brackish fossil assemblages are consistent with deposition in swamps or between distributary channels of the bayhead-delta system. Locally, the development of oligotrophic and/or poorly oxygenated conditions possibly prevented colonization by an autochthonous ostracod fauna.

Facies E6: Mollusc-rich clay with sand intercalations (outer-estuary facies

association)

Description. This facies association is composed of soft grey clays and silty clays with sandy silt and silty sand intercalations. Plant and wood fragments are only occasionally encountered. Pocket penetration tests show compressive strength values $<1.2 \mathrm{~kg} \mathrm{~cm}^{-2}$. Cone resistance is generally $<1 \mathrm{MPa}$. Pore pressure, generally $>u_{0}$, increases linearly with depth. This facies association is characterized by oligotypic macrobenthic assemblages clustered in discrete horizons. (Fig. 4D). The most abundant mollusc species are the brackish semelid Abra segmentum, commonly associated with C. glaucum or, in less confined areas, with the small corbulid Lentidium mediterraneum and the grazer gastropod Bittium spp. A very abundant meiofauna, dominated by typically euryhaline species (C. torosa and A. tepida-Ammonia parkinsoniana), characterizes this facies association. Loxoconcha elliptica, Haynesina germanica and Aubygnina perlucida are also commonly recorded. A local increase in species diversity is recorded by brackish to marine ostracods (Leptocythere species and Pontocythere turbida), along with several Miliolid taxa, mainly belonging to Miliolinella, Quinqueloculina and Pseudotriloculina genera, and poorly preserved, large specimens of Ammonia beccarii. This facies association is encountered at depths $>12 \mathrm{~m}$ in the central part of the study area, with a thickness of 5 to $7 \mathrm{~m}$. At more distal locations, it is just a few decimetres thick and shows updip transition to facies E1, E3 and E5.

Interpretation. Based on textural elements and on fossil assemblages, this facies association is inferred to have been deposited in a semienclosed brackish environment, like an estuary or a lagoon. Given the updip transition to riverdominated facies (E1 and E3), which implies mixing of fluvial and marine sources, the estuarine interpretation is preferred (Boyd et al., 2006). The C. torosa-A. tepida-A. parkinsoniana assemblage is a reliable indicator of a permanently submerged, semi-enclosed brackish-water basin subject to salinity changes. Palaeontological data allow interpretation of different degrees of marine influence within this facies association. Specifically, the increase in species diversity and in relative abundance of brackish to marine taxa (i.e. Leptocythere and Pseudotriloculina species, P. turbida, L. mediterraneum and Bittium spp.) points to less restricted/more open marine conditions.

\section{Nearshore (N) depositional system}

\section{Facies N1: Fossiliferous, well-sorted sands} (transgressive-barrier complex)

Description. This facies association consists of fossiliferous, well-sorted, medium to fine, grey sands. A scarce, poorly preserved meiofauna including shallow-marine species ( $P$. turbida and $A$. beccarii), and locally accompanied by scattered valves of C. torosa and L. elliptica, is recorded. Wood fragments and vegetal remains are seldom encountered. The lower boundary with the estuarine facies associations (E3 and E6) is erosional and consists of a lag of reworked shells of brackish and shallow-marine molluscs (Fig. 4E). This facies association was encountered in the eastern and central parts of the study area, where it grades landward into facies association E6. It is laterally discontinuous (Fig 2), and its thickness varies updip from a few decimetres to about $3 \mathrm{~m}$. In CPTU tests, $q_{\mathrm{c}}$ values rarely exceed $10 \mathrm{Mpa}$. Pore pressure is negative.

Interpretation. The combination of lithology and fossil content indicates a high-energy coastal environment. Due to their poor lateral continuity and landward transition to estuarine facies associations, these deposits are interpreted as transgressive barriers, similar to those mapped in the Northern Adriatic (Correggiari et al., 1996; Cattaneo \& Trincardi, 1999). The shell-rich lag at the base reflects the effect of wave erosion and reworking of backshore and upper shoreface strata during barrier retreat (wave ravinement surface of Swift, 1968; RS in Fig. 4E). The reduced thickness suggests erosion of upper shoreface strata, most probably cannibalized during shoreface retreat. 
Facies N2: Offshore transition

Description. This facies association consists of a thin $(<1 \mathrm{~m})$ veneer of soft, grey clays, with abundant microfossils and macrofossils. Small plant-tissue fragments and decomposed organic material are rarely encountered. Relatively highdiversity assemblages of marine macrofossils, including nuculids, mangelids and naticids, are commonly retrieved. This facies association was encountered in the most distal cores, above facies association N1. It is overlain by 20 to $30 \mathrm{~m}$ thick prodelta clays, characterized by oligotypic mollusc (Turritella and Corbula)-rich intervals. Resistance to penetration is low (PP $\left.<1 \mathrm{~kg} \mathrm{~cm}^{-2} ; q_{\mathrm{c}}<1 \mathrm{Mpa}\right)$.

Interpretation. The combination of lithology, consistency and fossil content suggests deposition in a low-energy, shallow-marine environment (offshore transition). Because this facies association shares many textural characteristics with the overlying prodelta clays, its identification was based mainly on palaeobiological criteria. The macrofaunal content in offshore deposits shows consistently higher diversity than in prodelta facies (Scarponi \& Kowalewski, 2007). In addition, distinctive oligotypic horizons of Corbula or Turritella horizons are diagnostic of prodelta deposits (Scarponi et al., 2014).

\section{LATE QUATERNARY STRATIGRAPHIC ARCHITECTURE}

\section{Late Pleistocene versus early Holocene stratigraphy}

The depositional architecture of the uppermost $40 \mathrm{~m}$ in the study area was studied along four stratigraphic transects (Figs 2 and 5). Cross-sections in Figs 2 and $5 \mathrm{~A}$ extend up to $45 \mathrm{~km}$ landward of the modern coastline. Cross-sections in Figs 5B and 5C, $25 \mathrm{~km}$ and $20 \mathrm{~km}$ long, respectively, run parallel to the coast. A relatively thin succession of Pleistocene alluvial deposits (46 to $12 \mathrm{cal} \mathrm{kyr} \mathrm{BP}$ ) is overlain by a stratigraphically expanded succession of Holocene estuarine and deltaic deposits, up to $30 \mathrm{~m}$ thick in the most distal sector (Fig 2). The Pleistocene/Holocene boundary, corresponding to the YD palaeosol, dips $0.03^{\circ}$ eastward in the proximal part of Section South (Fig. 2). About $15 \mathrm{~km}$ from the eastern end of the section, a steep ramp connects the inclined surface to a wide plateau, which lies about $30 \mathrm{~m}$ below sea-level. The YD palaeosol also deepens towards the north (Fig. 5B), where it is replaced by a laterally extensive channel-belt sandbody, >10 $\mathrm{m}$ thick. The morphology of the YD palaeosol appears to have been controlled by the tectonic activity of buried thrusts (see location in Fig. 3), because all the pedogenized surfaces beneath the YD palaeosol are inclined towards the north-east (Figs 2 and 5) and flatten after a ramp located just above the most external buried thrusts (Fig. 2). The channelbelt sandbody shows an aggradational stacking pattern and includes early Holocene fluvialchannel bodies, as pointed out by the stratal relationship between fluvial-channel facies and laterally continuous peat layers (Fig. 5A and $5 \mathrm{~B})$.

\section{Parasequence architecture of the early Holocene succession}

The Holocene succession above the YD surface is characterized by a complex internal stratigraphic architecture. A deepening-upward succession, up to $11 \mathrm{~m}$ thick, including estuarine and shallow-marine facies, is comprised between the YD palaeosol and the MFS (Fig. 2). The maximum thickness was reconstructed in the central part of the study area. A retrogradational stacking pattern of facies is observed along dip (Figs 2 and 5A). The age of the deposits that overlie the YD palaeosol decreases landward, from about 10.5 to $7 \cdot 8 \mathrm{kyr}$ вр (Fig. 2).

Flooding surfaces (FSs) were traced at abrupt landward shifts of facies. In particular, marine FSs are associated with 'an abrupt increase of water depth' (Van Wagoner et al., 1988); their recognition was partly based on quantitative bathymetric estimates from mollusc assemblages (Scarponi \& Kowalewski, 2004; Wittmer et al., 2014). The landward equivalents of marine FSs were traced in the paralic realm, where fossil assemblages indicate an increase in salinity or a decrease in the degree of confinement (Amorosi et al., 2014b). In the adjacent continental system, FSs were traced tentatively at the abrupt rise in groundwater table (for example, transition from well-drained floodplain to poorly drained flood-basin deposits or from poorly drained flood basin to swamp or innerestuary facies). Because marine flooding is commonly associated with bayhead-delta backstepping (Anderson et al., 2008; Maddox et al., 2008; Hijma et al., 2009; Rodriguez et al., 2010) 

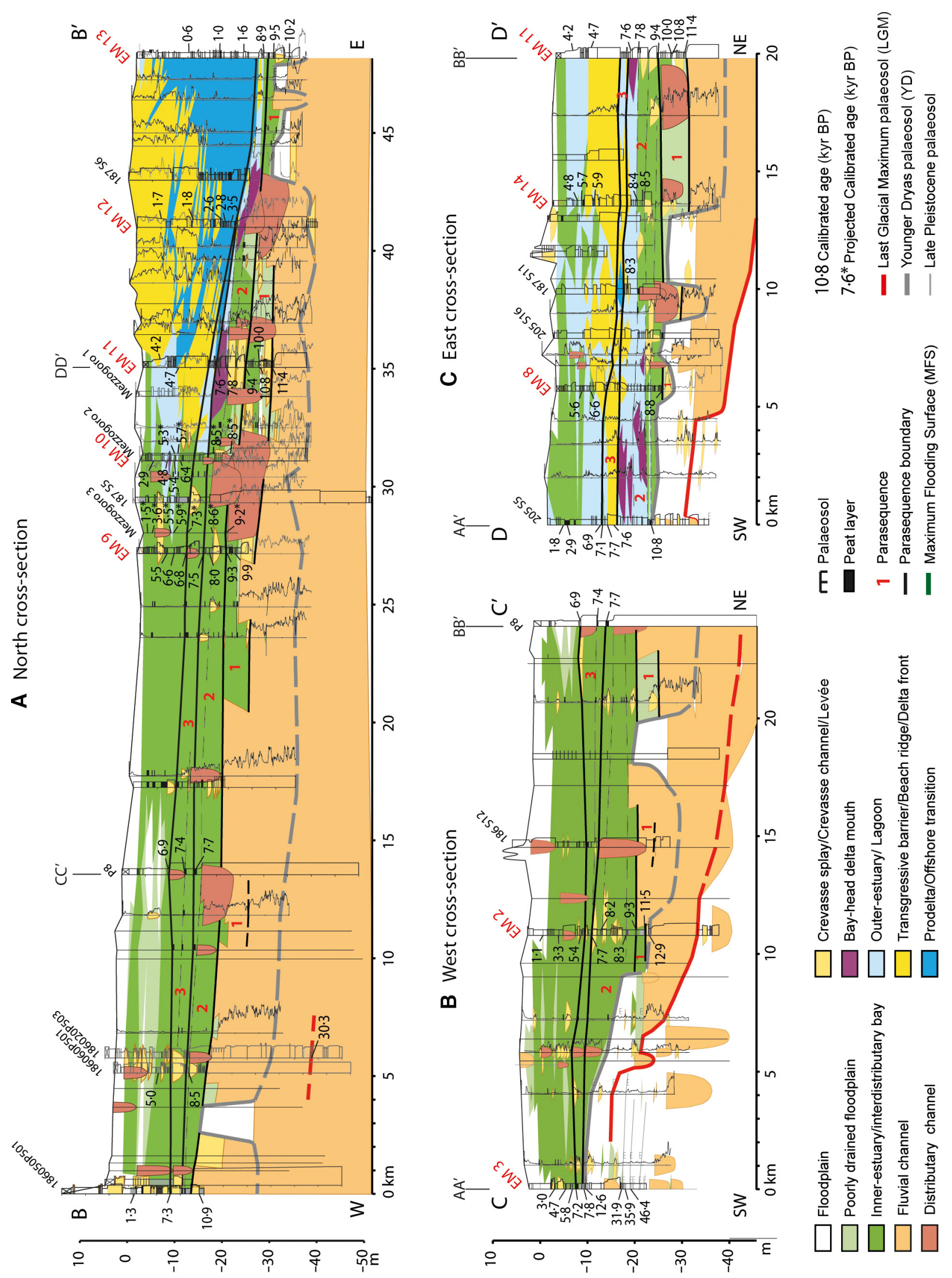
Fig. 5. Parasequence architecture of transgressive deposits along three correlation panels (see Fig. 3 for location). Reference cores (EM, 2014 to 2016 drilling campaign) are labelled in red, whereas core descriptions from the 1997 to 2001 drilling campaign are labelled in black (or in grey where projected). For details of radiocarbon dates, see Table 1.

and with substantial reorganization of the fluvial network within the drowning valley (Blum et al., 2013), FSs were also traced at the top of bayhead-delta and distributary-channel sand bodies. Peat horizons were used as a guide for stratigraphic correlation of FSs. Three prominent FSs, dated to about $11.5,9.2$ and $7.7 \mathrm{cal}$ kyr BP, respectively, were traced across the study area, marking the base of three parasequences. A landward shift of facies of several kilometres is recorded above these surfaces (Fig. 2). Minor flooding surfaces, associated with less significant backstepping of facies, were also identified (dashed lines in Figs 2 and 5). The FSs onlap the YD palaeosol (Fig. 2). In cross-section North (Fig. 5A), FSs are slightly deformed above the culmination of the buried anticlines (see also Fig. 3).

Parasequence 1 (11.5 to $9.2 \mathrm{cal} \mathrm{kyr}$ вр) was identified in the most distal part of cross-section South (Fig. 2), where the YD palaeosol is deeper. It is a tabular sediment body, up to $3 \mathrm{~m}$ thick, composed of poorly drained flood-basin deposits, with subordinate fluvial facies. Poorly drained flood-basin deposits are replaced northward by organic-matter-rich clays (facies association E5, Fig. 5A). The base of this parasequence corresponds to the YD palaeosol to the south and to a $10 \mathrm{~cm}$ thick peat layer at the top of laterally extensive fluvial bodies in the north-east (Fig. 5A). The peat layer was dated at 11.5 to $11.4 \mathrm{cal} \mathrm{kyr}$ BP in cores EM2 and EM11 (see Table 1). Fluvial-channel deposits become increasingly abundant towards the north-west, making the recognition of the basal FS difficult. The top of parasequence 1 is a $c a$ $10 \mathrm{~cm}$ thick peat layer, dated to $9 \cdot 4$ to $9 \cdot 3 \mathrm{cal}$ kyr BP in cores EM2, EM9 and EM11 and 8.9 to $8 \cdot 8 \mathrm{cal} \mathrm{kyr}$ BP in cores EM7 and EM8. This discrepancy can be interpreted assuming that the FS formed diachronously across the study area. Alternatively, the organic material composing the $10 \mathrm{~cm}$ thick peat layer may have been deposited in about six centuries, and thus the obtained age can be dramatically affected by the stratigraphic position of the dated sample within the peaty horizon. Parasequence 2 (9.2 to $7 \cdot 7$ cal year вP) consists of a set of lower-rank, backstepping sequences (Swift et al., 1991), bounded by minor FSs. Each subsequence, covering a time span of a few centuries, includes estuarine and nearshore facies associations. The oldest subsequence lacks nearshore sediments, probably located in the Adriatic area. The oldest transgressive-barrier complex, dated to about $8.5 \mathrm{cal} \mathrm{kyr}$ вP, was identified at $c a 25 \mathrm{~m}$ depth beneath the modern coastline (cores 205S9, Fig. 2 and EM13, Fig. 5A). Younger transgressive sand bodies are located in more inland positions, at higher stratigraphic levels. Bayhead-delta mouth sediment bodies, generally $<2 \mathrm{~m}$ thick, are commonly encountered at the freshwater-brackish transition. Like transgressive barrier sands, these sedimentary bodies exhibit a retrogradational stacking pattern.

Parasequence 3 (7.7 to $7.0 \mathrm{cal}$ year $\mathrm{BP})$ documents the maximum marine ingression. Above the FS, corresponding to a peat layer dated to 7.8 to 7.5 cal kyr вр (see cores EM2, EM3, EM9, 204S6 and P8; Figs 2 and 5), nearshore and outer-estuary facies show a landward shift of $c a$ $10 \mathrm{~km}$. Contrary to what was observed in parasequence 2, coastal retreat above the 7.7 FS occurred in a single step. The innermost transgressive-barrier sandbody is dated to about $7.5 \mathrm{cal} \mathrm{kyr}$ вP. Landward, it is transitional to a large bayhead-delta sandbody. Behind the bayhead-delta mouth, distributary channels are $<3 \mathrm{~m}$ thick and appear as isolated bodies (Figs 2, 5A and 5B). The shoreline trajectory is reversed above the $7 \cdot 0 \mathrm{cal}$ kyr BP surface, with coastal sediments encountered at progressively more distal locations (Figs 2 and $5 \mathrm{~A}$ ).

\section{DISCUSSION}

\section{Early Holocene evolution of the Po Coastal Plain}

Four maps, illustrating the evolution of the Po coastal plain during the early Holocene (Fig. 6), were reconstructed on the basis of the cross-sections of Figs 2 and 5. Each map depicts the dominant facies association between two consecutive flooding surfaces (FSs). 

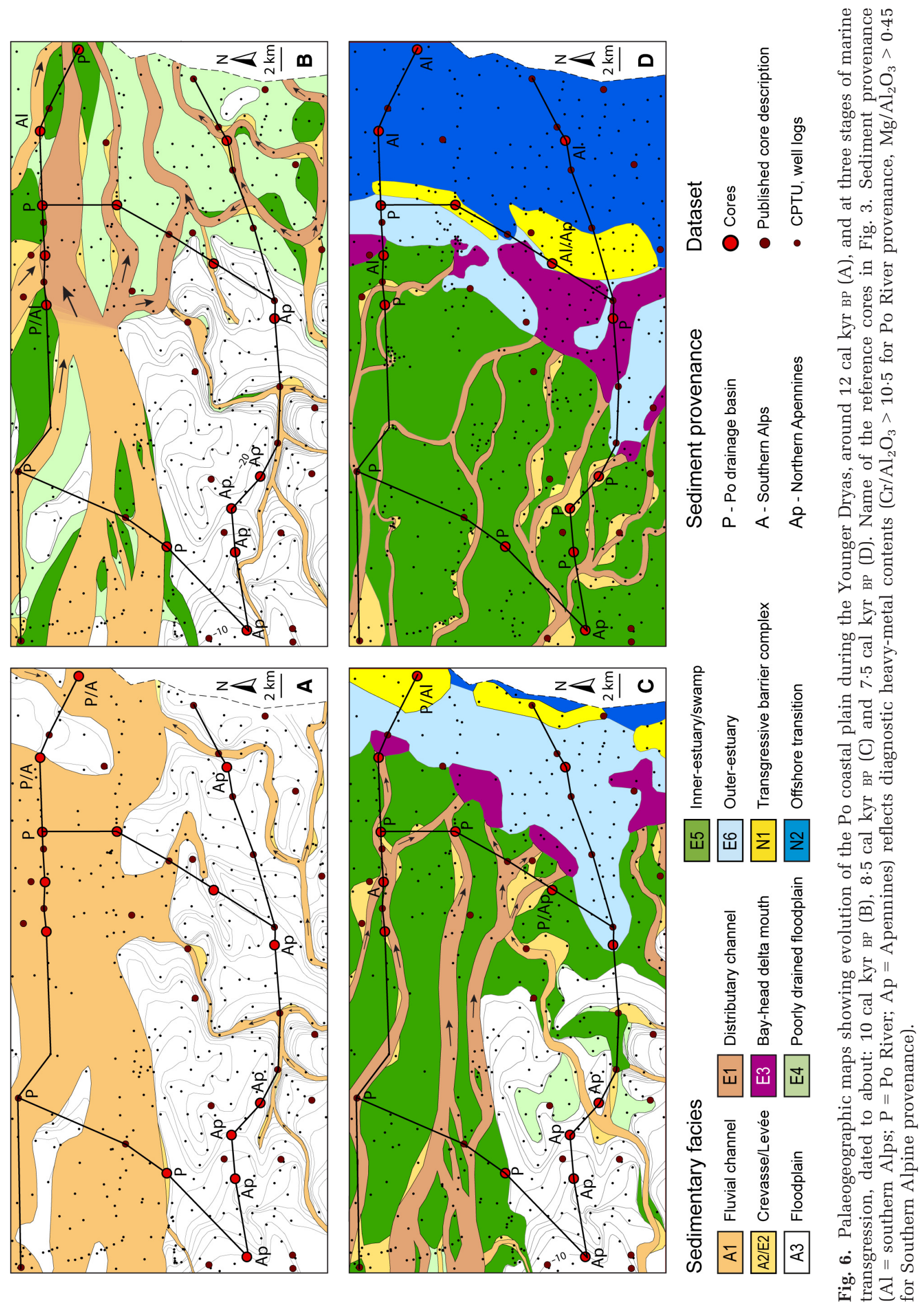

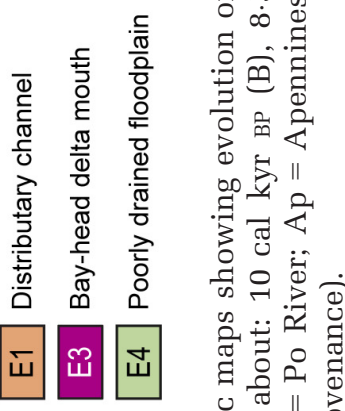

공

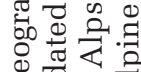

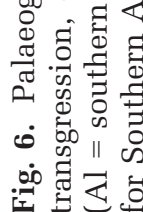


During the Younger Dryas, around $12 \mathrm{kyr}$ BP, the study area was a wide alluvial plain, tens of kilometres from its coeval coastline (Maselli et al., 2011; Amorosi et al., 2016b). Its southern portion was subaerially exposed and fluvial sedimentation was restricted to narrow rivers fed from Apennine sources (Fig. 6A). Based on more than 200 data points ( $c a 0.3$ point $\mathrm{km}^{-2}$ ), the morphology of the YD surface was reconstructed through $1 \mathrm{~m}$ spaced contour lines. This surface dips towards the north-east, with maximum gradient in the south-western region. To the north, the YD surface is replaced by an $8 \mathrm{~km}$ wide channel-belt sandbody elongated in a west-east direction. Based on its geometry, sedimentological characteristics and geochemical signature, it is interpreted as being deposited by a laterally migrating Po River. Mixed Alpine-Po provenance, in the north-eastern corner of the study area, probably reflects proximity of the confluence to Alpine tributaries.

Around 10 kyr BP, poorly drained and swampy environments developed in topographically depressed areas (Fig. 6B). Poorly drained flood basins prevailed to the south-east, whereas swamps were increasingly abundant in the north. The south-western sector was still subaerially exposed. The river network switched from tributive to partly avulsive/distributive, and the Po River was divided into three branches. The northern branch, which received sediment from Alpine tributaries, was the widest. The southern branch was a narrower, sinuous channel fed by Apenninic rivers. The central branch has similar width as the southern branch, but is less sinuous. Crevasse and levée facies are highly preserved in this stratigraphic interval.

Due to high facies variability within parasequence 2, the mapped interval was restricted to the second subsequence, approximately dated to 8.5 cal kyr BP (Figs 2 and 5). This map (Fig. 6C) depicts the typical geomorphic configuration of a wave-dominated estuary (Boyd et al., 2006), including: (i) coastal sand bodies at the estuary mouth; (ii) a low-energy basin (facies association E6); and (iii) a river-dominated sector, including bayhead-delta and inner-estuary facies, at the head. The transgressive barriers, elongated in SSW-NNE direction, show a mixed composition, with a diagnostic south Alpine signature. Po River sediments were trapped in a back-barrier. Outer-estuary sediments formed a $6 \mathrm{~km}$ wide stretch parallel to the transgressivebarrier complex. A relatively large area was occupied by inner-estuary and bayhead-delta facies associations. Outer-estuary sediments penetrated further inland, far from bayheaddelta mouths. The estuary was confined to the south-west by a topographic high that was subaerially exposed.

Figure 6D shows facies distribution between 7.7 and $7.0 \mathrm{cal}$ kyr вP. Transgressive barriers backstepped about $10 \mathrm{~km}$ in $c a 1 \mathrm{kyr}$ (cf Fig. 6C), at a rate of $c a 10 \mathrm{~m}_{\text {year }}{ }^{-1}$. The shoreline trajectory suggests that shoreface retreat slowed throughout parasequence 2 , and aggradation progressively prevailed over retrogradation (Fig. 2). The geochemical signature of the youngest transgressive sands indicates a mixed Alpine/Apenninic composition (Fig. 6D). A narrow stretch of outer-estuary sediments was preserved in the north, whereas to the south, a large bayhead-delta mouth sediment body filled the estuary and prograded onto coastal barriers (Fig. 6D). The south-western sector was entirely flooded and Po distributary channels spread over a wider area. As the width of terminal distributary-channel bodies may be smaller than mean data spacing (Olariu \& Bhattacharya, 2006), the number of distributary channels could be underestimated.

\section{Factors controlling environmental evolution}

The stratigraphic architecture and volume of estuarine deposits may result from the combination of several factors, including: (i) eustasy; (ii) sediment supply; (iii) basin physiography; and (iv) antecedent topography (Cattaneo \& Steel, 2003).

\section{Eustasy versus sediment supply}

The onlap of the early Holocene FSs onto the YD palaeosol, documented by progressively younger radiocarbon ages in updip positions (Fig. 2), testifies to the progressive drowning of the Po coastal plain between about 11.5 and $7 \cdot 0$ cal kyr BP. This phase marks the latest stages of the post-LGM, stepwise eustatic rise recorded at global scale (Fairbanks, 1989; Chappel \& Polach, 1991; Bard et al., 1996, 2010) and in the Mediterranean (Lambeck et al., 2011; Vacchi et al., 2016).

Two major sedimentary events are recorded in the study area around 11.5 cal kyr BP: (i) the Po River system became avulsive/distributive; and (ii) poorly drained flood basins and wetlands developed between distributary channels. The eastern sector in Fig. 6B is interpreted here as 
the apex of a large bayhead-delta plain (see also Hijma \& Cohen, 2011), which was correlative to a transgressive-barrier system identified in the Adriatic about $50 \mathrm{~km}$ off the modern coastline (Correggiari et al., 2005; Storms et al., 2008). The boundary between tributive and distributive parts of the fluvial systems migrates in response to shoreline translation (Boyd et al., 2006; Blum et al., 2013, and references therein). In particular, river systems become avulsive, distributive and aggrading as they enter their backwater lengths (Blum \& Törnqvist, 2000). Channel superelevation induced high groundwater table and the development of waterlogged areas. These environmental changes are interpreted as a response to the landward shift of several kilometres of the coastline documented in the Northern Adriatic (Trincardi et al., 1994). Although the timing and magnitude of MWP-1B are still debated (Abdul et al., 2016; Bard et al., 2016; Mortlock et al., 2016), the data herein suggest that sea-level rise accelerated after $11.5 \mathrm{cal}$ kyr вр.

Multiple events of transgressive-barrier and bayhead-delta retrogradation occurred between about 9.2 and $7.7 \mathrm{cal} \mathrm{kyr} \mathrm{BP} \mathrm{(Fig.} \mathrm{2),} \mathrm{in} \mathrm{response} \mathrm{to}$ phases of accelerated sea-level rise (around 9.2 and 8.4 cal kyr ве; Liu et al., 2004, 2007; Törnqvist et al., 2004; Hori \& Saito, 2007; Turney \& Brown, 2007; Kendall et al., 2008; Kleiven \& Kissel, 2008; Hijma \& Cohen, 2010; Li et al., 2012). The lowerrank units identified within parasequence 2 may reflect minor pulsations of sea-level rise or local subsidence induced by sediment compaction. The Po estuary backstepped across the study area at a mean rate of $10 \mathrm{~m}$ year $^{-1}$. The high rate of sealevel rise, exceeding the rate of fluvial sediment supply, inhibited bayhead-delta progradation, as testified to by the scarce lateral extent of bayheaddelta mouth deposits (Figs 2 and 6C). In contrast, high accommodation favoured sediment accumulation and preservation in distributary channels, crevasse splays and interdistributary areas (Aslan \& Blum, 1999; Slingerland \& Smith, 2004). After MWP-1D (8.0 to $7.5 \mathrm{cal} \mathrm{kyr}$ вP), the shoreline reached its maximum inland position. Due to the slackening of sea-level rise after 7.5 cal kyr BP, sediment supply exceeded the rate of accommodation increase, favouring the progradation of bayheaddelta mouths and the partial filling of the central basin (Fig. 6D).

Several worldwide records show evidence of rapid transgression around $11.5 \mathrm{cal}$ kyr BP (Maddox et al., 2008; Delgado et al., 2012; Milli et al., 2013), $9 \cdot 5$ to $9 \cdot 2$ cal kyr вр (Hori et al., 2002; Zong et al., 2009; Amorosi et al., 2013; Tanabe et al., 2015), 8.5 to $8.3 \mathrm{cal} \mathrm{kyr}$ вр (Yim et al., 2006; Troiani et al., 2011; Amorosi et al., 2013; Boski et al., 2015) and 8.0 to $7 \cdot 3 \mathrm{cal} \mathrm{kyr}$ вP (Heap \& Nichol, 1997; Li et al., 2002; Abrahim et al., 2008; Trog et al., 2013; Breda et al., 2016), thus supporting the hypothesis of a dominant control of eustasy on parasequence architecture.

\section{Basin physiography and sediment dispersal}

Around $11 \mathrm{cal}$ kyr BP the Northern Adriatic was characterized by an oceanographic regime comparable with the modern. Counterclockwise circulation, transporting sediments from north to south along the Italian coast, was already established (Cattaneo \& Trincardi, 1999; Storms et al., 2008; Pellegrini et al., 2015). The geochemical signature of the transgressive-barrier deposits (Fig. 6C and 6D) confirms the existence of south-heading currents, which transported alongshore Mg-rich (i.e. dolomite-rich) sediments delivered by rivers draining the southern Alps. Part of the transgressive-barrier sand may also derive from reworking of older barriers, as indicated by the mixed Alpine/Apenninic composition (Fig. 6D) and by the wide range of ages obtained from fossils collected in this facies association (Scarponi et al., 2013; 2017). Sediments fed by the Po River accumulated within the estuary (Fig. 6C and 6D), where the highest sedimentation rates ( 5 to $6 \mathrm{~mm} \mathrm{year}^{-1}$ ) are recorded. Rapid aggradation was probably favoured by a significant terrigenous sediment input and by the presence of the barrier, which reduced the impact of marine processes. The wide area occupied by fluvial-dominated facies associations, compared with the narrow brackish zone in the back-barrier position (Fig. 6C), suggests that fluvial processes were dominant within the Po estuary. Sediment trapping in the estuary resulted in reduced sediment influx to the basin, as testified to by the reduced thickness of offshore-transition deposits.

\section{Eustasy versus antecedent topography}

The morphology of the transgressed surface is a key factor controlling estuary development and evolution (Heap \& Nichol, 1997; Dillenburg et al., 2000; Rodriguez et al., 2005; Abrahim et al., 2008; Anderson et al., 2008; Rossi et al., 2011; Simms \& Rodriguez, 2015). Low-gradient transgressive surfaces favour rapid landward shifts of facies, whereas the presence of structural highs may limit the emplacement of transgressive deposits (Cattaneo \& Steel, 2003). The 
thickness and preservation potential of transgressive deposits are generally high within palaeovalleys and low on interfluves (Dalrymple et al., 1992; Zaitlin et al., 1994).

In the case of drowned palaeovalleys, antecedent topography substantially coincides with valley morphology. The Po estuary was not confined in a deep palaeovalley and also developed on interfluves (i.e. above the YD palaeosol). Due to the combined effect of local tectonics/subsidence and river incision, the YD surface was characterized by an irregular morphology, with differences in elevation $>20 \mathrm{~m}$ (Fig. 6A). The thickness and internal facies configuration of transgressive deposits, and the pattern of estuary evolution reflect this complex morphology: low-lying interfluvial areas were drowned in the early stages of estuary formation (Fig. 6B), whereas the more elevated interfluves were flooded only at peak transgression (Fig. 6C and 6D). The originally topography was smoothed by the emplacement of parasequence 1 , and transgressive sedimentation after 9.2 cal kyr вP occurred on a nearly horizontal surface (parasequence 2). Rapid barrier retreat was forced by high rates of eustatic rise, probably enhanced by the extremely low gradient of the submerged surface.

\section{CONCLUSIONS}

The early Holocene palaeogeographic evolution of the Adriatic coastline and of the Po River system provides insights into the complex modalities of retreat of a coastal system during a phase of rapid eustatic rise. Based on an extensive data set composed of 14 cores, 28 core descriptions and more than 300 piezocone tests (CPTUs), with the chronological support of 137 radiocarbon dates, the main results of this study are:

1 A deepening-upward succession of early Holocene estuarine to shallow-marine facies overlies Late Pleistocene alluvial deposits. The Pleistocene/Holocene boundary locally coincides with a weakly developed palaeosol, formed during the Younger Dryas (YD) cold reversal. The retrogradational pattern of the early Holocene succession testifies to the progressive drowning of the Po coastal plain in response to post-Last Glacial Maximum (LGM) eustatic rise.

2 Three main flooding surfaces and their landward equivalents were recognized within the early Holocene succession and dated to about 11.5, $9 \cdot 2$ and $7 \cdot 7 \mathrm{kyr}$ вр. These surfaces mark the base of three transgressive parasequences that developed in response to the major pulses of early Holocene eustatic rise.

3 Between 11.5 and $7 \cdot 0 \mathrm{kyr}$ BP, a wave-dominated estuary migrated landward, across the study area. Three main geomorphic features were reconstructed: a transgressive-barrier complex at the mouth of the estuary, a narrow central basin behind the barrier and a wide bayhead-delta system at the head.

4 The complex morphology of the YD surface influenced facies evolution in the initial stages of estuary formation (11.5 to $9.2 \mathrm{kyr}$ вP). The Po estuary was initially confined in a shallow valley and then spread onto low-lying interfluvial areas. The fluvial system then became avulsive/distributive. The most elevated floodplains remained subaerially exposed until 7.7 cal kyr вр.

5 The emplacement of parasequence 1 resulted in a very low-relief surface that favoured high rates of barrier retreat after $9.2 \mathrm{kyr}$ вр. The transgressive barriers migrated landward between $9 \cdot 2$ and $7.7 \mathrm{kyr}$ вP, at the rate of $c a 10 \mathrm{~m} \mathrm{year}^{-1}$. Shoreline retreat did not occur in a single step, but was punctuated by centennial-scale flooding events. The rate of retrogradation decreased during the whole interval and changed progressively to aggradation. The shoreline reached its maximum inland position around $7 \cdot 7 \mathrm{kyr}$ BP. The flattening of the eustatic curve favoured bayhead-delta progradation and the partial filling of the central basin.

6 Sediment supplied by the Po River and by its tributaries was partitioned in the estuarine realm and in the coastal realm, respectively. Coastal sand bodies were fed by south-directed longshore currents and by the landward transfer of sands eroded from older transgressive barriers.

\section{ACKNOWLEDGEMENTS}

This research is part of a collaborative research project supported by ExxonMobil Upstream Research Company. We are indebted to Joe Macquaker and Mike Sweet for their constructive review of an early version of the manuscript. This article was improved by the helpful suggestions of reviewers Salvatore Milli, Kim Cohen and Alexander Simms.

\section{REFERENCES}

Abdul, N.A., Mortlock, R.A., Wright, J.D. and Fairbanks, R.G. (2016) Younger Dryas sea level and meltwater pulse 
1B recorded in Barbados reef crest coral Acropora palmate. Paleocenography, 31, 330344.

Abrahim, G.M.S., Nichol, S.L., Parker, R.J. and Gregory, M.R. (2008) Facies depositional setting, mineral maturity and sequence stratigraphy of a Holocene drowned valley, Tamaki Estuary, New Zealand. Estuar. Coast. Shelf Sci., 79, 133142.

Allen, G.P. and Posamentier, H.W. (1993) Sequence stratigraphy and facies model of an incised valley fill: the Gironde Estuary, France. J. Sed. Petrol., 63, 378391.

Amorosi, A. and Marchi, N. (1999) High resolution sequence stratigraphy from piezocone tests: an example from the Late Quaternary deposits of the SE Po Plain. Sed. Geol., 128, 6983.

Amorosi, A. and Milli, S. (2001) Late Quaternary depositional architecture of Po and Tevere river deltas (Italy) and worldwide comparison with coeval deltaic successions. Sed. Geol., 144, 357375.

Amorosi, A., Colalongo, M.L., Pasini, G. and Preti, D. (1999) Sedimentary response to Late Quaternary sea level changes in the Romagna coastal plain (northern Italy). Sedimentology, 46, 99121.

Amorosi, A., Centineo, M.C., Dinelli, E., Lucchini, F. and Tateo, F. (2002) Geochemical and mineralogical variations as indicators of provenance changes in Late Quaternary deposits of SE Po Plain. Sed. Geol., 151, 273292.

Amorosi, A., Centineo, M.C., Colalongo, M.L., Pasini, G., Sarti, G. and Vaiani, S.C. (2003) Facies architecture and Latest Pleistocene Holocene depositional history of the Po Delta (Comacchio area), Italy. J. Geol., 111, 3956.

Amorosi, A., Centineo, M.C., Colalongo, M.L. and Fiorini, F. (2005) Millennial scale depositional cycles from the Holocene of the Po Plain, Italy. Mari. Geol., 222 223, 718.

Amorosi, A., Pavesi, M., Ricci Lucchi, M., Sarti, G. and Piccin, A. (2008) Climatic signature of cyclic fluvial architecture from the Quaternary of the central Po plain, Italy. Sed. Geol., 209, 5868.

Amorosi, A., Rossi, V. and Vella, C. (2013) Stepwise post glacial transgression in the Rhône Delta area as revealed by high resolution core data. Palaeogeogr. Palaeoclimatol. Palaeoecol., 374, 314326.

Amorosi, A., Guermandi, M., Marchi, N. and Sammartino, I. (2014a) Fingerprinting sedimentary and soil units by their natural metal contents: a new approach to assess metal contamination. Sci. Total Environ., 500 501, 361372.

Amorosi, A., Rossi, V., Scarponi, D., Vaiani, S.C. and Ghosh, A. (2014b) Biosedimentary record of postglacial coastal dynamics: high resolution sequence stratigraphy from the northern Tuscan coast (Italy). Boreas, 43, 939954.

Amorosi, A., Bruno, L., Rossi, V., Severi, P. and Hajdas, I. (2014c) Paleosol architecture of a late Quaternary basin margin sequence and its implications for high resolution, non marine sequence stratigraphy. Global Planet. Change, 112, 1225 .

Amorosi, A., Bruno, L., Cleveland, D.M., Morelli, A. and Hong, W. (2016a) Paleosols and associated channel belt sand bodies from a continuously subsiding late Quaternary system (Po Basin, Italy): new insights into continental sequence stratigraphy. Geol. Soc. Am. Bull., in press. https://doi.org/10.1130/b31575.1

Amorosi, A., Maselli, V. and Trincardi, F. (2016b) Onshore to offshore anatomy of a late Quaternary source to sink system (Po Plain Adriatic Sea, Italy). Earth Sci. Rev., 153, 212237.
Amorosi, A., Bruno, L., Campo, B., Morelli, A., Rossi, V., Scarponi, D., Hong, W., Bohacs, K.M. and Drexler, T.M. (2017) Global sea level control on local parasequence architecture from the Holocene record of the Po Plain, Italy. Mar. Petrol. Geol, doi: 10.1016/j.marpetgeo.2017.01. 020. in press.

Amos, C.L. and Knoll, R.G. (1987) The Quaternary sediments of Banquereau, Scotian Shelf. Geol. Soc. Am. Bull., 99, 244260.

Anderson, J.B., Rodriguez, A.B., Milliken, K.T. and Taviani, M. (2008) The Holocene evolution of the Galveston estuary complex, Texas: evidence for rapid change in estuarine environments. In: Response of Upper Gulf Coast Estuaries to Holocene Climate Change and Sea Level Rise (Eds J.B. Anderson and A.B. Rodriguez), Geol. Soc. Am. Spec. Pap., 443, 89104.

Andrés Giagante, D.A., Aliotta, S., Ginsberg, S.S., Vecchi, L.G. and Spagnuolo, J.O. (2011) Evolution of a coastal alluvial deposit in response to the last Quaternary marine transgression, Bahía Blanca estuary, Argentina. Quatern. Res., 75, 614623.

Aslan, A. and Blum, M.D. (1999) Contrasting styles of Holocene avulsion, Texas Gulf Coastal Plain. In: Fluvial Sedimentology VI (Eds N.D. Smith and J.J. Rogers), Int. Assoc. Sedimentol. Spec. Publ., 28, 193209.

Austermann, J., Mitrovica, J.X., Latychev, K. and Milne, G.A. (2013) Barbados based estimate of ice volume at Last Glacial Maximum affected by subducted plate. Nat. Geosci., 6, 553557.

Bard, E., Hamelin, B., Arnold, M., Montaggioni, L., Cabioch, G., Faure, G. and Rougerie, F. (1996) Deglacial sea level record from Tahiti corals and the timing of global meltwater discharge. Nature, 382, 241244.

Bard, E., Hamelin, B. and Delanghe-Sabatier, D. (2010) Deglacial meltwater pulse $1 \mathrm{~B}$ and Younger Dryas sea levels revisited with boreholes in Tahiti. Science, 327, 12351237.

Bard, E., Hamelin, B., Deschamps, P. and Camoin, G. (2016) Comment on "Younger Dryas sea level and meltwater pulse 1B recorded in Barbados reefal crest coral Acropora palmata" by N. A. Abdul, R. A. Mortlock, J. D. Wright and R.G. Fairbanks. Paleocenography, 31, 16031608.

Berendsen, H.J.A. and Stouthamer, E. (2000) Palaeogeographical Development of the Rhine Meuse Delta. Van Gorcum, Assen, The Netherlands. 250 pp.

Bhattacharya, J.P. (2006) Deltas. In: Facies Models Revisited (Eds. R.G. Walker and H. Posamentier), SEPM Spec. Publ., 84, 237292.

Blum, M.D. and Roberts, H.H. (2012) The Mississippi delta region: past, present, and future. Annu. Rev. Earth Planet. Sci., 40, 655683.

Blum, M.D. and Tornqvist, T.E. (2000) Fluvial responses to climate and sea level change: a review and look forward. Sedimentology, 47, 248.

Blum, M.D., Martin, J., Milliken, K. and Garvin, M. (2013) Paleovalley systems: insights from Quaternary analogs and experiments. Earth Sci. Rev., 116, 128169.

Boccaletti, M., Corti, G. and Martelli, L. (2011) Recent and active tectonics of the external zone of the Northern Apennines (Italy). Int. J. Earth Sci., 100, 13311348

Boski, T., Bezerra, F.H.R., De Fátima Pereira, L., Souza, A.M., Maia, R.P. and Lima Filho, F.P. (2015) Sea level rise since $8.2 \mathrm{ka}$ recorded in the sediments of the Potengi Jundiai Estuary, NE Brasil. Mar. Geol., 365, 113. 
Boyd, R., Dalrymple, R.W. and Zaitlin, B.A. (2006) Estuarine and incised valley facies models. In: Facies Models Revisited (Eds H.W. Posamentier and R.G. Walker), SEPM Spec. Publ., 84, 171235.

Breda, A., Amorosi, A., Rossi, V. and Fusco, F. (2016) Late glacial to Holocene depositional architecture of the Ombrone paleovalley system (Southern Tuscany, Italy): sea level, climate and local control in valley fill variability. Sedimentology, 63, 11241148.

Bronk Ramsey, C. (2009) Dealing with outliers and offsets in radiocarbon dating. Radiocarbon, 51, 10231045.

Bruno, L., Amorosi, A., Severi, P. and Costagli, B. (2017) Late Quaternary aggradation rates and stratigraphic architecture of the southern Po Plain, Italy. Basin Res., 29, 234248.

Carlini, M., Artoni, A., Aldega, L., Balestrieri, M.L., Corrado, S., Vescovi, P., Bernini, M. and Torelli, L. (2013) Exhumation and reshaping of far travelled/allochthonous tectonic units in mountain belts. New insights for the relationships between shortening and coeval extension in the western Northern Apennines (Italy). Tectonophysics, 608, 267287.

Cattaneo, A. and Steel, R.J. (2003) Transgressive deposits: a review of their variability. Earth Sci. Rev., 62, 187228.

Cattaneo, A. and Trincardi, F. (1999) The Late Quaternary transgressive record in the Adriatic epicontinental sea: basin widening and facies partitioning. In: Isolated Shallow Marine Sand Bodies: Sequence Stratigraphic Analysis and Sedimentological Interpretation (Eds K.M. Bergman and J.W. Snedden), SEPM Spec. Publ., 64, 127146.

Cattaneo, A., Correggiari, A., Langone, L. and Trincardi, F. (2003) The late Holocene Gargano subaqueous delta, Adriatic shelf: sediment pathways and supply fluctuations. Mar. Geol., 193, 6191.

Cawthra, H.C., Bateman, M.D., Carr, A.S., Compton, J.S. and Holmes, P.J. (2014) Understanding Late Quaternary change at the land ocean interface: a synthesis of the evolution of the Wilderness coastline, South Africa. Quatern. Sci. Rev., 99, 210223.

Chappell, J. and Polach, H. (1991) Post glacial sea level rise from a coral record at Houn Peninsula, Papua New Guinea. Nature, 349, 147149.

Chaumillon, E., Tessier, B. and Reynaud, J.Y. (2010) Stratigraphic records and variability of incised valleys and estuaries along French coasts. Bull. Soc. Géol. France, 181, 7585.

Ciabatti, M., Curzi, P.V. and Ricci Lucchi, F. (1987) Quaternary sedimentation in the Central Adriatic Sea. Giorn. Geol., 49, 113125.

Clark, P.U., Mitrovica, J.X., Milne, G.A., Turon, J.L. and Siani, G. (2002) Sea level fingerprint as a direct test for the source of global Meltwater Pulse 1A. Science, 295, 24382441.

Codegone, G., Festa, A., Dilek, Y. and Pini, G.A. (2012) Small scale polygenetic mélanges in the Ligurian accretionary complex, Northern Apennines, Italy, and the role of shale diapirism in superposed mélange evolution in orogenic belts. Tectonophysics, 568 569, 170184.

Coleman, J.M. and Wright, L.D. (1975) Modern river deltas: variability of processes and sand bodies. In: Deltas, Models for Exploration (Ed. M.L. Broussard), pp. 99149. Houston Geological Society, Houston.

Correggiari, A., Roveri, M. and Trincardi, F. (1996) Late Pleistocene and Holocene evolution of the North Adriatic sea. II Quaternario, Ital. J. Quatern. Sci., 9, 697704.
Correggiari, A., Cattaneo, A. and Trincardi, F. (2005) Depositional patterns in the Late Holocene Po delta system. In: Concepts, Models and Examples (Eds J.P. Bhattacharya and L. Giosan), SEPM Spec. Publ., 83, 365 392.

Dalrymple, R.W., Zaitlin, B.A. and Boyd, R. (1992) Estuarine facies models, conceptual basis and stratigraphic implications. J. Sed. Petrol., 62, 11301146.

Delgado, J., Boski, T., Nieto, J.M., Pereira, L., Moura, D., Gomes, A., Sousa, C. and García-Tenorio, R. (2012) Sea level rise and anthropogenic activities recorded in the late Pleistocene/Holocene sedimentary infill of the Guadiana Estuary (SW Iberia). Quatern. Sci. Rev., 33, 121141.

Dillenburg, S.R., Roy, S.P., Cowell, P.J. and Tomazelli, L.J. (2000) Influence of antecedent topography on coastal evolution as tested by the Shoreface Translation Barrier Model (STM). J. Coastal Res., 16, 7181.

Elliott, T. (1986) Deltas. In: Sedimentary Environments and Facies (Ed. H.G. Reading), pp. 113 154. Blackwell Scientific Publications, Oxford.

Fairbanks, R.G. (1989) A 17,000 year glacio eustatic sea level record influence of glacial melting rates on the Younger Dryas event and deep sea circulation. Nature, 342, 637642 .

Foyle, A.M. and Oertel, G.F. (1997) Transgressive systems tract development and incised valley fills within a Quaternary estuary shelf system: virginia inner shelf, USA. Mar. Geol., 137, 227249.

Frignani, M., Langone, L., Ravaioli, M., Sorgente, D., Alvisi, F. and Albertazzi, S. (2005) Finesediment mass balance in the western Adriatic continental shelf over a century time scale. Mar. Geol., 222 223, 113133.

Gile, L.H., Hawley, J.W. and Grossman, R.B. (1981) Soils and Geomorphology in the Basin and Range Area of Southern New Mexico Guidebook to the Desert Project. New Mexico Bureau of Mines and Mineral Resources, Socorro, New Mexico. 222 pp.

Green, A.N. (2009) Palaeo drainage, incised valley fills and transgressive systems tract sedimentation of the northern KwaZulu Natal continental shelf, South Africa, SW Indian Ocean. Mar. Geol., 263, 4663.

Gregoire, L.J., Payne, A.J. and Valdes, P.J. (2012) Deglacial rapid sea level rises caused 6 by ice sheet saddle collapses. Nature, 487, 219222.

Heap, A.D. and Nichol, S.L. (1997) The influence of limited accommodation space on the stratigraphy of an incised valley succession: weiti River estuary, New Zealand. Mar. Geol., 144, 229252.

Hijma, M.P. and Cohen, K.M. (2010) Timing and magnitude of the sea level jump preluding the $8200 \mathrm{yr}$ event. Geology, 38, 275278.

Hijma, M.P. and Cohen, K.M. (2011) Holocene transgression of the Rhine river mouth area, The Netherlands/Southern North Sea: palaeogeography and sequence stratigraphy. Sedimentology, 58, 14531485.

Hijma, M.P., Cohen, K.M., Hoffmann, G., Van der Spek, A.J.F. and Stouthamer, E. (2009) From river valley to estuary: the evolution of the Rhine mouth in the early to middle Holocene (western Netherlands, Rhine Meuse delta). Netherlands J. Geosci., 88, 1353.

Hori, K. and Saito, Y. (2007) An early Holocene sea level jump and delta initiation. Geophys. Res. Lett., 34, L18401. https://doi.org/10.1029/2007GL031029.

Hori, K., Saito, Y., Zhao, Q. and Wang, P. (2002) Evolution of the coastal depositional systems of the Changjiang 
(Yangtze) River in response to late Pleistocene Holocene sea level changes. J. Sed. Res., 72, 884897.

Ishii, Y., Hori, K., Momohara, A., Nakanishi, T. and Hong, W. (2016) Middle to late Holocene decreased fluvial aggradation and widespread peat initiation in the Ishikari lowland (northern Japan). The Holocene, 26, 19241938.

Kendall, R.A., Mitrovica, J.X., Milne, G.A., Tornqvist, T.E. and Li, Y. (2008) The sea level fingerprint of the $8.2 \mathrm{ka}$ climate event. Geology, 36, 423426.

Kleiven, H. and Kissel, C. (2008) Reduced North Atlantic deep water coeval with the glacial lake Agassiz freshwater outburst. Science, 5859, 6064.

Kowalewski, M., Wittmer, J.M., Dexter, T.A., Amorosi, A. and Scarponi, D. (2015) Differential responses of marine communities to natural and anthropogenic changes. Proc. $R$. Soc. B, 20142990. https://doi.org/10.1098/rspb.2014.2990

Lambeck, K. and Purcell, A. (2005) Sea level change in the Mediterranean Sea since the LGM: model predictions for tectonically stable areas. Quatern. Sci. Rev., 24, 1969 1988.

Lambeck, K., Antonioli, F., Anzidei, M., Ferranti, L., Leoni, G., Scicchitano, G. and Silenzi, S. (2011) Sea level change along the Italian coast during the Holocene and projections for the future. Quatern. Int., 232, 250257.

Li, C.X., Chen, Q.Q., Zhang, J.Q., Yang, S.Y. and Fan, D.D. (2000) Stratigraphy and paleoenvironmental changes in the Yangtze Delta during the late Quaternary. J. Asian Earth Sci., 18, 453469.

Li, C., Wang, P., Sun, H., Zhang, J., Fan, D. and Deng, B. (2002) Late Quaternary incised valley fill of the Yangtze delta (China): its stratigraphic framework and evolution. Sed. Geol., 152, 133158.

Li, Y., Tornqvist, T.E., Nevitt, J.M. and Kohl, B. (2012) Synchronizing a sea level jump, final Lake Agassiz drainage, and abrupt cooling 8200 years ago. Earth Planet. Sci. Lett., 315 316, 4150.

Liu, J.P., Milliman, J.D., Gao, S. and Cheng, P. (2004) Holocene development of the Yellow River's subaqueous delta, North Yellow Sea. Mar. Geol., 209, 4567.

Liu, J., Saito, Y., Hong, W., Yang, Z. and Nakashima, R. (2007) Sedimentary evolution of the Holocene subaqueous clinoform off the Shandong Peninsula in the Yellow Sea. Mar. Geol., 236, 165187.

Machette, M.N. (1985) Calcic soils of the southwestern United States. Geol. Soc. Am. Spec. Pap., 203, 121.

Maddox, J., Anderson, J.B., Milliken, K.T., Rodriguez, A.B., Dellapenna, T.M. and Giosan, L. (2008) The Holocene evolution of the Matagorda and Lavaca estuary complex, Texas, USA. In: Response of Upper Gulf Coast Estuaries to Holocene Climate Change and Sea Level Rise (Eds J.B. Anderson and A.B. Rodriguez), Geol. Soc. Am. Spec, Pap., 443, 105119.

Malanotte Rizzoli, P. and Bergamasco, A. (1983) The dynamics of the coastal region of the northern Adriatic Sea. J. Phys. Oceanogr., 13, 11051130.

Marchesini, L., Amorosi, A., Cibin, U., Zuffa, G.G., Spadafora, E. and Preti, D. (2000) Sand composition and sedimentary evolution of a Late Quaternary depositional sequence, northwestern Adriatic Coast, Italy. J. Sed. Res., 70, 829838.

Maselli, V., Hutton, E.W., Kettner, A.J., Syvitski, J.P.M. and Trincardi, F. (2011) High frequency sea level and sediment supply fluctuations during Termination I: an integrated sequence stratigraphy and modeling approach from the Adriatic Sea (Central Mediterranean). Mar. Geol., 287, 5470 .

McGranahan, G., Balk, D. and Anderson, B. (2007) The rising tide: assessing the risks of climate change and human settlements in low elevation coastal zones. Environ. Urbanisation, 19, 1737.

Milli, S., D'ambrogi, C., Bellotti, P., Calderoni, G., Carboni, M.G., Celant, A., Di Bella, L., Di Rita, F., Frezza, V., Magri, D., Pichezzi, R.M. and Ricci, V. (2013) The transition from wave dominated estuary to wave dominated delta: the Late Quaternary stratigraphic architecture of Tiber deltaic succession (Italy). Sed. Geol., 284 285, 159180.

Milli, S., Mancini, M., Moscatelli, M., Stigliano, F., Marini, M. and Cavinato, G.P. (2016) From river to shelf, anatomy of a high frequency depositional sequence: the Late Pleistocene Holocene Tiber Depositional Sequence. Sedimentology, 63, 18432277.

Miola, A., Bondesan, A., Corain, L., Favaretto, S., Mozzi, P., Piovan, S. and Sostizzo, I. (2006) Wetlands in the Venetian Po Plain (north eastern Italy) during the Last Glacial Maximum: vegetation, hydrology, sedimentary environments. Rev. Palaeobot. Palynol., 141, 5381.

Mortlock, R.A., Abdul, N.A., Wright, J.D. and Fairbanks, R.G. (2016) Reply to comment by E. Bard et al. on "Younger Dryas sea level and meltwater pulse 1B recorded in Barbados reef crest coral Acropora palmata" by N. A. Abdul et al.. Paleocenography, 31, 16091616.

Moscon, G., Correggiari, A., Stefani, C., Fontana, A. and Remia, A. (2015) Very high resolution analysis of a transgressive deposit in the Northern Adriatic sea (Italy). Alpine Mediterr. Quatern., 28, 121129.

Muttoni, G., Carcano, C., Garzanti, E., Ghielmi, M., Piccin, A., Pini, R., Rogledi, S. and Sciunnach, D. (2003) Onset of major Pleistocene glaciations in the Alps. Geology, 31, 989992.

Neal, J. and Abreu, V. (2009) Sequence stratigraphy hierarchy and the accommodation succession method. Geology, 37, 779782.

Olariu, C. and Bhattacharya, J.P. (2006) Terminal distributary channels and delta front architecture of river dominated delta systems. J. Sed. Res., 76, 212233.

Ori, G.G., Roveri, M. and Vannoni, F. (1986) Plio Pleistocene sedimentation in the Apenninic Adriatic foredeep (Central Adriatic Sea, Italy). In: Foreland Basins (Eds P.A. Allen and P. Homewood), Int. Assoc. Sedimentol. Spec. Publ., 8, 183198.

Pellegrini, C., Maselli, V., Cattaneo, A., Piva, A., Ceregato, A. and Trincardi, F. (2015) Anatomy of a compound delta from the post glacial transgressive record in the Adriatic Sea. Mar. Geol., 362, 4359.

Pieri, M. and Groppi, G. (1981) Subsurface geological structure of the Po Plain, Italy. In: Progetto Finalizzato Geodinamica (Eds M. Pieri and G. Groppi), 414th edn, pp. 1 23. C.N.R, Roma.

Reimer, P.J., Bard, E., Bayliss, A., Beck, J.W., Blackwell, P.G., Bronk Ramsey, C., Buck, C.E., Cheng, H., Edwards, R.L., Friedrich, M., Grootes, P.M., Guilderson, T.P., Haflidason, H., Hajdas, I., Hatté, C., Heaton, T.J., Hoffmann, D.L., Hogg, A.G., Hughen, K.A., Kaiser, K.F., Kromer, B., Manning, S.W., Niu, M., Reimer, R.W., Richards, D.A., Scott, E.A., Southon, J.R., Staff, R.A., Turney, C.S.M. and Van Der Plicht, J. (2013) IntCal13 and Marine13 radiocarbon age calibration curves, 0 50,000 years cal BP. Radiocarbon, 55, 18691887. 
Ricci Lucchi, F. (1986) Oligocene to recent foreland basins of northern Apennines. In: Foreland Basins (Eds P. Allen and P. Homewood), Int. Assoc. Sedimentol. Spec. Publ., 8, 105139.

Rodriguez, A.B., Anderson, J.B. and Simms, A.R. (2005) Terrace inundation as an autocyclic mechanism for parasequence formation: galveston estuary, Texas, U.S.A. J. Sed. Res., 75, 608620.

Rodriguez, A.B., Simms, A.R. and Anderson, J.B. (2010) Bay head deltas across the northern Gulf of Mexico back step in response to the $8.2 \mathrm{ka}$ cooling event. Quatern. Sci. Rev., 29, 39833993.

Rossi, V., Amorosi, A., Sarti, G. and Potenza, M. (2011) Influence of inherited topography on the Holocene sedimentary evolution of coastal systems: an example from Arno coastal plain (Tuscany, Italy). Geomorphology, 135, 117128

Scarponi, D. and Kowalewski, M. (2004) Stratigraphic paleoecology: bathymetric signatures and sequence overprint of mollusk associations from upper Quaternary sequences of the Po Plain, Italy. Geology, 32, 989992.

Scarponi, D. and Kowalewski, M. (2007) Sequence stratigraphic anatomy of diversity patterns: late Quaternary benthic mollusks of the Po Plain, Italy. Palaios, 22, 296305.

Scarponi, D., Kaufman, D., Amorosi, A. and Kowalewski, M. (2013) Sequence stratigraphy and the resolution of the fossil record. Geology, 41, 239242.

Scarponi, D., Huntley, J.W., Capraro, L. and Raffi, S. (2014) Stratigraphic paleoecology of the Valle di Manche section (Crotone Basin, Italy): a candidate GSSP of the Middle Pleistocene. Palaeogeogr. Palaeoclimatol. Palaeoecol., 402, 3043.

Scarponi, D., Azzarone, M., Kusnerik, K., Amorosi, A., Bohacs, K.M., Drexler, T.M. and Kowalewski, M. (2017) Systematic vertical and lateral changes in quality and time resolution of the macrofossil record: insights from Holocene transgressive deposits, Po coastal plain, Italy. Mar. Petrol. Geol., doi: 10.1016/j.marpetgeo.2017. 03.031.

Schwarz, E., Veiga, G.D., Spalletti, L.A. and Massaferro, J.L. (2011) The transgressive infill of an inherited valley system: the Springhill Formation (lower Cretaceous) in southern Austral Basin, Argentina. Mar. Petrol. Geol., 28, 12181241.

Simms, A.R. and Rodriguez, A.B. (2015) The Influence of valley morphology on the rate of bayhead delta progradation. J. Sed. Res, 85, 3844.

Slingerland, R.L. and Smith, N.D. (2004) River avulsions and their deposits. Annu. Rev. Earth Planet. Sci., 32, 255 283

Soil Survey Staff (1999) Soil Taxonomy. A Basic System of Soil Classification for Making and Interpreting Soil Surveys. Agricultural Handbook, 2nd edn. no. 436: Natural Resources Conservation Service, USDA, Washington DC, 886 pp.

Somoza, L., Barnolas, A., Arasa, A., Maestro, A., Rees, J.G. and Hernandez-Molina, F.J. (1998) Architectural stacking patterns of the Ebro delta controlled by Holocene high frequency eustatic fluctuations, delta lobe switching and subsidence processes. Sed. Geol., 117, 1132.

Storms, J.E.A., Weltje, G.J., Terra, G.J., Cattaneo, A. and Trincardi, F. (2008) Coastal dynamics under conditions of rapid sea level rise: late Pleistocene to Early Holocene evolution of barrier lagoon systems on the northern Adriatic shelf (Italy). Quatern. Sci. Rev., 27, 11071123

Swift, D.J.P. (1968) Coastal erosion and transgressive stratigraphy. J. Geol., 76, 444456.

Swift, D.J.P., Phillips, S. and Thorne, J.A. (1991) Sedimentation on continental margins: V. Parasequences. In: Shelf Sand and Sandstone Bodies Geometry, Facies and Sequence Stratigraphy (Eds D.J.P. Swift, G.F. Oertel, R.W. Tillman and J.A. Thorne), Int. Assoc. Sedimentol. Spec. Publ., 14, 153187.

Syvitski, J.P.M. and Kettner, A.J. (2007) On the flux of water and sediment into the Northern Adriatic Sea. Cont. Shelf Res., 27, 296308.

Ta, T.K.O., Nguyen, V.L., Tateishi, M., Kobayashi, I. and Saito, Y. (2005) Holocene delta evolution and depositional models of the Mekong River Delta, Southern Vietnam. In: River Deltas Concepts, Models, and Examples (Eds L. Giosan and J.P. Bhattacharya), SEPM Spec. Publ., 83, 453466.

Tanabe, S., Nakanishi, T., Ishihara, Y. and Nakashima, R. (2015) Millennial scale stratigraphy of a tide dominated incised valley during the last $14 \mathrm{kyr}$ : spatial and quantitative reconstruction in the Tokyo Lowland, central Japan. Sedimentology, 62, 18371872.

Tinterri, R. and Tagliaferri, A. (2015) The syntectonic evolution of foredeep turbidites related to basin segmentation: facies response to the increase in tectonic confinement (Marnoso arenacea Formation, Miocene, Northern Apennines, Italy). Mar. Petrol. Geol., 67, 81110.

Tornqvist, T.E., Bick, S.J., González, J.L., Van der Borg, K. and De Jong, A.F.M. (2004) Tracking the sea level signature of the 8.2 ka cooling event: new constraints from the Mississippi Delta. Geophys. Res. Lett., 31, L23309. https://doi.org/10.1029/2004gl021429.

Traini, C., Menier, D., Proust, J.N. and Sorrel, P. (2013) Transgressive systems tract of a ria type estuary: the Late Holocene Vilaine River drowned valley (France). Mar. Geol., 337, 140155.

Trincardi, F., Correggiari, A. and Roveri, M. (1994) Late Quaternary transgressive erosion and deposition in a modern epicontinental shelf: the Adriatic semienclosed basin. Geo Mar. Lett., 14, 4151.

Trincardi, F., Cattaneo, A., Asioli, A., Correggiari, A. and Langone, L. (1996) Stratigraphy of the Late Quaternary deposits in the central Adriatic basin and the record of short term climatic events. Mem. Istit. Ital. Idrobiol., $\mathbf{5 5}$, 3970 .

Trog, C., Hofer, D., Frenzel, P., Camacho, S., Schneider, H. and Mausbacher, R. (2013) A multi proxy reconstruction and comparison of Holocene palaeoenvironmental changes in the Alvor and Alcantarilha estuaries (southern Portugal). Rev. Micropaléontol., 56, 131158.

Troiani, T., Simms, A.R., Dellapenna, T., Piper, E. and Yokoyama, Y. (2011) The importance of sea level and climate change, including wind energy, on the evolution of a coastal estuary: Copano Bay, Texas. Mar. Geol., 280, 119.

Turney, C.S.M. and Brown, H. (2007) Catastrophic early Holocene sea level rise, human migration and the Neolithic transition in Europe. Quatern. Sci. Rev., 26, 20362041.

Vacchi, M., Marriner, N., Morhange, C., Spada, G., Fontana, A. and Rovere, A. (2016) Multiproxy assessment of Holocene relative sea level changes in the western Mediterranean: sea level variability and improvements in the definition of the isostatic signal. Earth Sci. Rev., 155, 172197. 
Van Wagoner, J.C., Posamentier, H.W., Mitchum, R.M., Vail, P.R., Sarg, J.F., Loutit, T.S. and Hardenbol, J. (1988) An overview of the fundamentals of sequence stratigraphy and key definitions. In: Sea Level Changes: An Integrated Approach (Eds C.K. Wilgus, B.S. Hastings, C.G.St.C. Kendall, H.W. Posamentier, C.A. Ross and J.C. Van Wagoner), SEPM Spec. Publ., 42, 39 45.

Vis, G.-J., Kasse, C. and Vandenberghe, J. (2008) Late Pleistocene and Holocene palaeogeography of the Lower Tagus Valley (Portugal): effects of relative sea level, valley morphology and sediment supply. Quatern. Sci. Rev., 27, 16821709.

Wang, X.H. and Pinardi, N. (2002) Modelling the dynamics of sediment transport and resuspension in the northern Adriatic Sea. J. Geophys. Res., 107, 3225. https://doi.org/ 10.1029/2001jc001303.

Wittmer, J.M., Dexter, T., Scarponi, D., Amorosi, A. and Kowalewski, M. (2014) Quantitative bathymetric models for late Quaternary transgressive regressive cycles of the Po Plain, Italy. J. Geol., 122, 649670.
Yim, W.W.S., Huang, G., Fontugne, M.R., Hale, R.E., Paterne, M., Pirazzoli, P.A. and Ridley Thomas, W.N. (2006) Postglacial sea level changes in the northern South China Sea continental shelf: evidence for a post 8200 calendar yr BP meltwater pulse. Quatern. Int., 145 146, 5567.

Zaitlin, B.A., Dalrymple, R.W. and Boyd, R. (1994) The stratigraphic organization of incised valley systems associated with relative sea level change. In: Incised Valley Systems: Origin and Sedimentary Sequences (Eds R.W. Dalrymple, R. Boyd and B.A. Zaitlin), SEPM Spec. Publ., 51, 4560.

Zavatarelli, M., Raicich, F., Bregant, D., Russo, A. and Artegiani, A. (1998) Climatological biogeochemical characteristics of the Adriatic Sea. J. Mar. Syst., 18, 227263.

Zong, Y., Yim, W.W.-S., Yu, F. and Huang, G. (2009) Late Quaternary environmental changes in the Pearl River mouth region, China. Quatern. Int., 206, 3545. 